\title{
26. CARBONATE ACCUMULATION IN THE INDIAN OCEAN DURING THE PLIOCENE: EVIDENCE FOR A CHANGE IN PRODUCTIVITY AND PRESERVATION AT ABOUT $2.4 \mathrm{Ma}^{1}$
}

\author{
William B. Curry, ${ }^{2}$ James L. Cullen, ${ }^{3}$ and Jan Backman ${ }^{4}$
}

\begin{abstract}
We measured carbonate concentrations in Pleistocene and Pliocene sediments deposited at Sites 709, 710, and 711. Carbonate concentrations exhibit low-amplitude, long-wave length (300-400 k.y. period) variations at the shallowest sites (709 and 710). Before $2.47 \mathrm{Ma}$, all three sites exhibit higher frequency (100 k.y. period) variations. The deepest site (711) exhibited low-amplitude variations and very low concentrations up to the Gauss/Matuyama magnetic reversal $(2.47 \mathrm{Ma})$, then concentrations abruptly increased. After $2.47 \mathrm{Ma}$, carbonate concentrations at Site 711 exhibited the same periodic changes as at Site 709 . Although a long wave-length periodicity (260-280 k.y.) occurs at these sites after $2.47 \mathrm{Ma}$, the $100 \mathrm{k} . \mathrm{y}$. period is absent. The dominant periods observed in these data are those found in the eccentricity component of the earth's orbital geometry.

Estimates of carbonate accumulation at Sites 709 and 710 document that surface-water productivity decreased near the Gauss/Matuyama magnetic reversal whereas accumulation at Site 711 increased. These results indicate that the rate of carbonate preservation in the deep Indian Ocean increased at that time. This increase in preservation may have resulted from a decrease in the production rate of carbonate in tropical oceans of the world. Carbonate accumulation estimated from sediments in shallow locations $(\sim 3000-3800 \mathrm{~m})$ of the Atlantic and Pacific oceans also indicates that carbonate production decreased at this time. A consequence of lowered surface-water productivity is increased carbonate ion concentration of the deep ocean and better preservation of carbonate on the seafloor.
\end{abstract}

\section{INTRODUCTION}

One of the principal goals of Ocean Drilling Program (ODP) Leg 115 was to reconstruct the history of carbonate sedimentation in the western Indian Ocean during the Neogene. The drilling strategy, to core a series of holes down the northern slope of the Madingley Rise, produced a series of three sites $(709,710$, and 711) that span the water depth interval from 3000 to $4400 \mathrm{~m}$. We have measured the carbonate concentration of the Pliocene sediments that spanned the interval associated with the most recent phase of Northern Hemisphere ice growth $(\sim 2.4 \mathrm{Ma})$. The purpose of our study is to determine what changes in the carbonate system occurred in response to this major change in the earth's climate.

Our research strategy is based on studies of late Quaternary sedimentation and sediment geochemistry that have successfully reconstructed many aspects of late Quaternary deep-water circulation and chemistry (Johnson et al., 1977; Curry and Lohmann, 1983, 1985, in press; Peterson and Prell, 1985a). This strategy invokes a basic assumption that the principal source of carbonate in the sediments at this location is from surface-water productivity, with little or no lateral input from advection or down-slope reworking. If this assumption is true, then carbonate accumulation in the shallowest sites, if they are always above the lysocline, is the best approximation of the past history of surface-water carbonate productivity. If the sites are located close to one another and not near any sharp gradients in surface-water productivity, then the input rate of carbonate from surface water should be nearly equal in all sites. Then the difference in accumulation between the shallowest and progressively deeper

\footnotetext{
${ }^{1}$ Duncan, R. A., Backman, J., Peterson, L. C., et al., 1990. Proc. ODP, Sci. Results, 115: College Station, TX (Ocean Drilling Program).

2 Department of Geology and Geophysics, Woods Hole Oceanographic Institution, Woods Hole, MA, 02543, U.S.A.

${ }^{3}$ Department of Geological Science, Salem State College, Salem, MA 01945, U.S.A.

${ }^{4}$ Department of Geology, University of Stockholm, Stockholm, Sweden.
}

sites is a quantitative estimate of the amount of carbonate lost to dissolution. Thus, our research strategy constrains the history of two important components of the carbonate system: carbonate productivity and dissolution.

\section{METHODS}

We employed a new, automated system to measure the carbonate concentration of the sediments. The system determines the carbonate concentration based on the amount of gas evolved during the chemical reaction of a known mass of dried sediment (0.01-0.02 g) in $100 \%$ phosphoric acid at a constant temperature of $80^{\circ} \mathrm{C}$. The pressure of the evolved gas is converted to mass of carbonate based on the regression line of pressure vs. mass of carbonate determined for pure carbonate samples reacted in the same system. Thus, the fraction of carbonate equals the ratio of the mass of carbonate estimated from this regression and the mass of raw sediment. The system is microprocessor controlled and interfaced with a digital balance (Ostermann et al., 1990), so that the only manual operations include placing the sediment samples into the reaction boats and loading the boats into the system. Based on three sets of replicate analyses of marine sediment samples, the precision of these measurements ranges from $\pm 0.5 \%$ to $0.8 \%$ (Fig. 1). We analyzed samples at 10-cm spacing in Site 709 and at $5-\mathrm{cm}$ spacing in Sites 710 and 711 for a total of 1097 analyses. The carbonate concentration data are presented in the Appendix.

\section{RESULTS}

\section{Site 709}

Two holes at this site $\left(3^{\circ} 55^{\prime} \mathrm{S}, 60^{\circ} 33^{\prime} \mathrm{E}, 3038 \mathrm{~m}\right.$ water depth) were cored with the advanced piston corer (APC) to a depth of about $200 \mathrm{~m}$. We analyzed the section from about $3 \mathrm{~m}$ below seafloor (mbsf) to $37 \mathrm{mbsf}$ in Hole 709B (Fig. 2). The carbonate concentration throughout this interval is fairly constant with an average value of $91.3 \% \pm 2.1 \%(N=335)$. These values are typical of shallow cores in this region (e.g., RC12-328) and result from a low input rate of noncarbonate, terrigenous sedimentary components and a low dissolution rate. All of the car- 


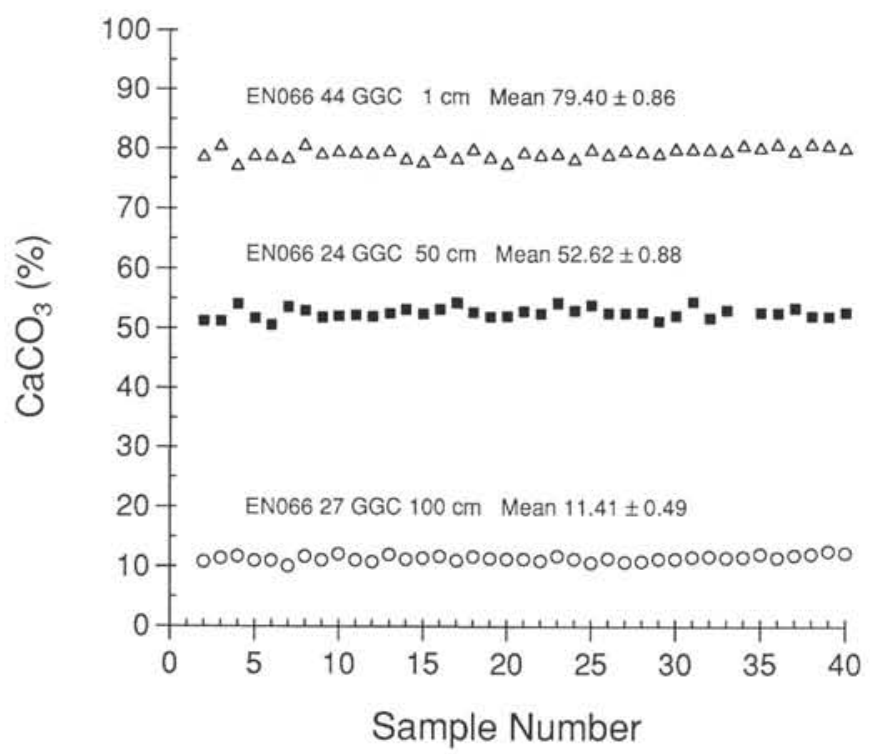

Figure 1. Replicate analyses of carbonate concentration for samples with high, medium, and low concentrations. The sediments are from Giant Gravity Cores (GGC) recovered during cruise Endeavor 066 (EN066) to the Sierra Leone Rise in the eastern equatorial Atlantic (Curry and Lohmann, 1985). The data were produced using an automated, digital, gasometric system with a precision of $\pm 0.5 \%-0.8 \%$ (Ostermann et al., 1990).

bonate concentrations fall between $86 \%$ and $97 \%$. Within this hole, seven magnetic reversals were identified (Schneider and Kent, this volume). We used four of these reversals to produce the time series of carbonate concentration.

\section{Site 710}

Two holes at this site $\left(4^{\circ} 19^{\prime} \mathrm{S}, 60^{\circ} 59^{\prime} \mathrm{E}, 3812 \mathrm{~m}\right.$ water depth) were cored with the APC. In Hole $710 \mathrm{~A}$ we analyzed samples from Cores $115-710 \mathrm{~A}-3 \mathrm{H}$ and $-4 \mathrm{H}$, and in Hole $710 \mathrm{~B}$ we analyzed samples from Cores $115-710 \mathrm{~B}-4 \mathrm{H}$ and $-5 \mathrm{H}$ (Fig. 3). Carbonate concentrations in Hole $710 \mathrm{~A}$ average $72.7 \% \pm 6.7 \%$ $(N=276)$ and in Hole $710 \mathrm{~B}$ they average $71.4 \% \pm 7.1 \%(N=$ 201). Carbonate concentrations exhibit greater variability in these holes than in Hole 709B. Minimum concentrations are generally $60 \%$ whereas maximum concentrations exceed $80 \%$. Magnetic reversals in these holes were used to produce a time series of carbonate concentration from $\sim 5 \mathrm{Ma}$ to $\sim 2.3 \mathrm{Ma}$ with a 200,000 yr gap at about $3 \mathrm{Ma}$.

\section{Site 711}

This site lies between the Madingley Rise and the Carlsberg Ridge $\left(2^{\circ} 45^{\prime} \mathrm{S}, 61^{\circ} 10^{\prime} \mathrm{E}, 4430\right.$-m water depth). Two holes were drilled at Site 711 , and we measured the carbonate concentration in Cores 115-711 A-2 $\mathrm{H}$ and $-3 \mathrm{H}$ for Hole $711 \mathrm{~A}$ and in Core 115-711B-3H for Hole 711B (Fig. 4). Carbonate concentrations average $27.5 \% \pm 17.9 \%(N=135)$ in Hole $711 \mathrm{~A}$ and $6.3 \% \pm$ $7.9 \%(N=150)$ in Hole 711B. Overall, the average carbonate concentration is $16.3 \% \pm 17.2 \%(N=285)$. In the deeper sections of these holes, very low carbonate concentrations were observed. At about $14 \mathrm{mbsf}$ in Hole $711 \mathrm{~A}$, the carbonate concentration abruptly increases to values that are consistently greater than about $25 \%$. Maximum values at about 9 mbsf reach $75 \%$. Magnetic reversals in these cores were identified (Schneider and Kent, this volume), and we have used these reversals to combine

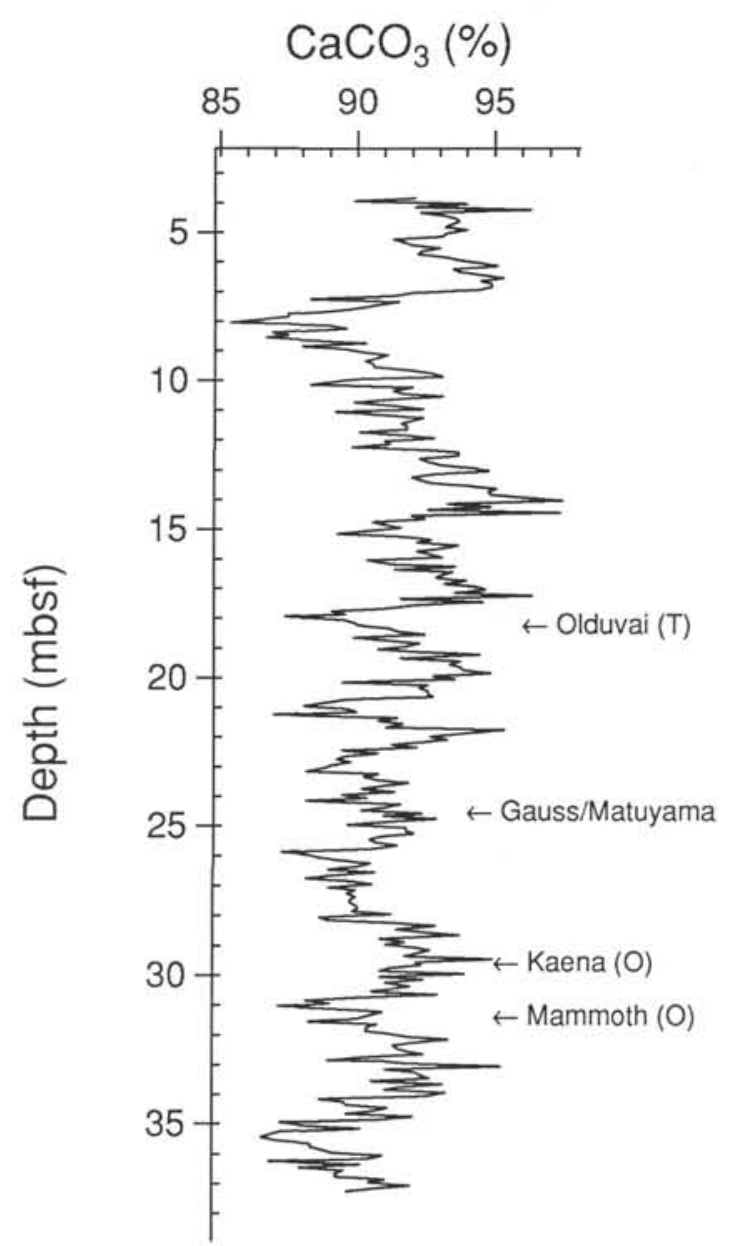

Figure 2. Carbonate concentrations in Hole 709B. Carbonate percentages average $91.3 \% \pm 2.1 \%$ in this hole. The four magnetic reversal boundaries (Schneider and Kent, this volume) identified in the figure were used to produce the time series of carbonate concentration presented in Figure 5.

the records to produce a continuous time series of carbonate concentration for this site for the interval from $\sim 5$ to $\sim 1.4 \mathrm{Ma}$.

\section{Carbonate Concentration Time Series}

Time series of carbonate concentration are plotted in Figure 5. Throughout the last $4 \mathrm{~m}$.y., the carbonate concentration in Hole $709 \mathrm{~B}$ does not exhibit any abrupt changes. The changes in concentration appear periodic with a long wave length $(\sim 400,000$ yr). In Site 710, the combined record includes intervals with very high-frequency changes in carbonate concentration. The combined record for Site 711 exhibits some very sharp changes in carbonate concentration that correlate with major events in the Pliocene isotopic record (Shackleton et al., 1984; Keigwin, 1986). At about $2.8 \mathrm{Ma}$, carbonate concentration increases from values near 0 to values that average $10 \%-20 \%$. At about $2.4 \mathrm{Ma}$, the carbonate concentration increases again to values that average $>30 \%$. The increase is very abrupt and, since the event at $2.4 \mathrm{Ma}$ occurs entirely within Hole $711 \mathrm{~A}$, it is not a result of combining the records from Holes 711A and 711B. This increase in concentration correlates with a major increase in $\delta^{18} \mathrm{O}$ observed above the Gauss/Matuyama magnetic reversal in many APC sites where Pliocene sediments have been recovered (Shack- 

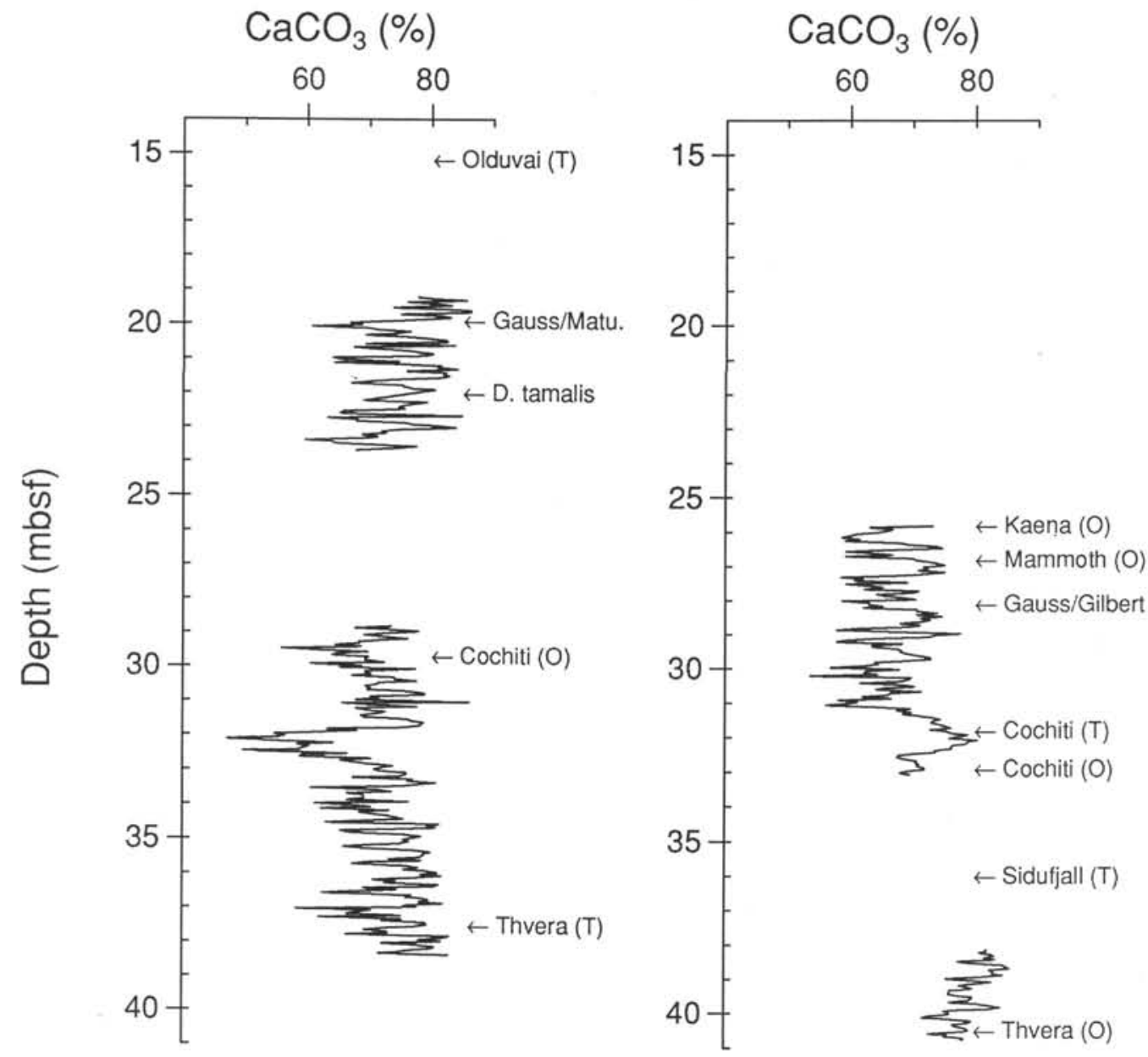

Figure 3. Carbonate concentrations in Holes 710A (left) and 710B (right). Carbonate percentages average $72.7 \% \pm 6.7 \%$ in Hole $710 \mathrm{~A}$ and $71.4 \% \pm 7.1 \%$ in Hole $710 \mathrm{~B}$. The identified magnetic reversals (Schneider and Kent, this volume) and one biostratigraphic boundary were used to combine the data sets and to produce the time-series record for Site 710, which is presented in Figure 5.

leton et al., 1984; Keigwin, 1986). The earlier increase in concentration at $2.8 \mathrm{Ma}$ correlates with isotopic events that predate the increase at $2.4 \mathrm{Ma}$ (Keigwin, 1986).

A low-frequency, periodic signal is apparent in the carbonate concentration record of Site 709. Decomposing this signal into its spectral components (Fig. 6) reveals high-amplitude variations at about a 400-k.y. period (frequency $=0.0025$ cycles/ k.y.) during the interval from 2.47 to $3.40 \mathrm{Ma}$. After $2.47 \mathrm{Ma}$, the most prominent period in the carbonate concentration record is about $267 \mathrm{k} . \mathrm{y}$. (frequency $=0.0037 \mathrm{cycles} / \mathrm{k} . \mathrm{y}$.). These same periodic changes are apparent in sections of Sites 710 and 711. Before the Gauss/Matuyama magnetic reversal, carbonate concentrations in Site 710 varied with a period of 333,000 400,000 yr. Following the Gauss/Matuyama magnetic reversal, carbonate concentrations in Site 711 varied with a period of about 285 k.y. (In Site 710, the record is too short to resolve any low-frequency changes in carbonate concentration after $2.47 \mathrm{Ma}$. In Site 711, low carbonate concentrations of small amplitude occurred before $2.47 \mathrm{Ma}$, so the record of low-frequency variations may be obscured.) Pisias and Prell (1985) also noted lowfrequency variations (period $=\sim 300 \mathrm{k}$.y.) in carbonate concentration in the Pliocene interval of Pacific Deep Sea Drilling Project (DSDP) Site 572. Periodic variations with a wave length of about $100 \mathrm{k} . \mathrm{y}$. occur in all three sites before $2.47 \mathrm{Ma}$, but they cannot be resolved after that time (Fig. 6).

\section{Bulk Density and Sediment Accumulation}

Shipboard measurements of dry-bulk density (dry wt/wet vol.) are plotted in Figure 7 with respect to their carbonate concentration. (Note: We used only those shipboard measurements from cores that we analyzed for carbonate concentration. Although there are many more bulk density measurements available, they are mostly from deeper sections in these holes and suffer from compaction because of sediment overburden.) The correlation coefficient between the two variables is $0.95(N=$ $25)$. The slope and intercept are very similar to those found in other equatorial regions (equatorial Pacific: Lyle and Dymond, 1976; eastern equatorial Atlantic: Curry and Lohmann, 1985, 1986), which indicates that similar sedimentary components have mixed at this location to produce the carbonate concentrations and bulk densities. In the equatorial Pacific and eastern equatorial Atlantic, the noncarbonate component is opaline silica, which has a grain density lower than calcium carbonate and terrigenous silicates. Addition of silica to the sediment lowers the carbonate concentration as well as the bulk density. In regions with low input of opaline silica but high input of terrigenous silicates, bulk density is more constant over a wide range of carbonate concentrations (Curry and Lohmann, in press).

We used the carbonate concentration, bulk density, and sedimentation rates to calculate the accumulation rate of carbonate 

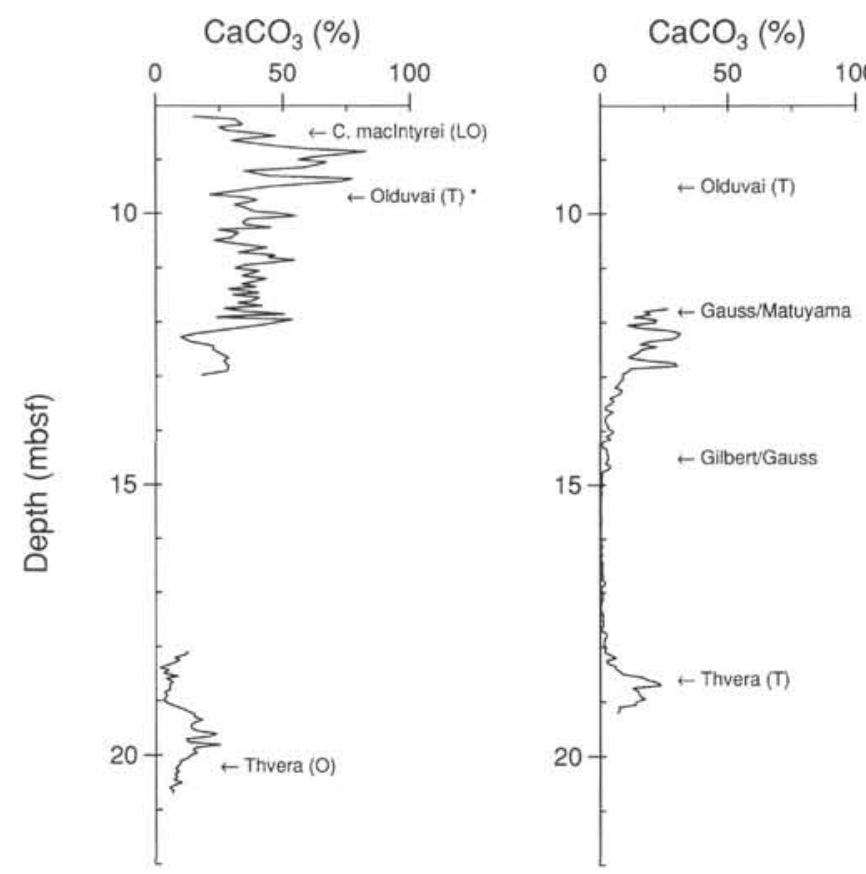

Figure 4. Carbonate concentrations in Holes 711A (left) and 711B (right). Carbonate percentages average $27.5 \% \pm 17.9 \%$ in Hole $711 \mathrm{~A}$ and $6.3 \% \pm 7.9 \%$ in Hole $711 \mathrm{~B}$. The identified magnetic reversals (Schneider and Kent, this volume) and one biostratigraphic boundary were used to combine the records and to produce the time-series record for Site 711, which is presented in Figure 5. Note that the Olduvai (T) reversal was not identified in Hole 711A. Its level in this hole was projected from the magnetic reversal record in Hole 711B by correlating their magnetic susceptibility records.

and noncarbonate sediment components for these sites so that we could evaluate the changes in productivity and preservation that affected this region during the Pliocene (Fig. 8). Average accumulation rates are presented for the intervals before and after the Gauss/Matuyama magnetic reversal (Table 1) because near this stratigraphic boundary a global increase in $\delta^{18} \mathrm{O}$ occurred that marks the most recent phase of Northern Hemisphere ice growth (Shackleton et al., 1984; Keigwin, 1986).

Before the Gauss/Matuyama boundary, carbonate accumulation in Hole $709 \mathrm{~B}$ averaged $0.74 \mathrm{~g} / \mathrm{cm}^{2} / \mathrm{k}$.y. After this magnetic reversal, the accumulation rate decreased to $0.62 \mathrm{~g} / \mathrm{cm}^{2}$ / k.y. This decrease in accumulation, if not accompanied by any change in dissolution at this shallow depth, must reflect a small decrease in the production of carbonate in the overlying surface water. (Note: The timing of the change in carbonate accumulation is not constrained by this data. In Figure 8, it occurs at 2.47 $\mathrm{Ma}$ only as an artifact because our chronology forces a change in sedimentation rate at that interval. Based on the changes in carbonate concentration at Site 711 that were caused by this decrease in carbonate productivity, we think that the decrease in carbonate accumulation may have occurred in two steps: at 2.8 $\mathrm{Ma}$ and $2.4 \mathrm{Ma}$.) Carbonate accumulation in Site 710 also decreased at about this time, from pre-Gauss/Matuyama values of $0.46 \mathrm{~g} / \mathrm{cm}^{2} / \mathrm{k}$.y. to post-Gauss/Matuyama values of $0.36 \mathrm{~g} / \mathrm{cm}^{2} /$ k.y. Although Site 710 is only $800 \mathrm{~m}$ deeper than Site $709,0.3 \mathrm{~g}$ / $\mathrm{cm}^{2} / \mathrm{k}$.y. (about $40 \%$ ) of carbonate on average have been lost to dissolution before and after the Gauss/Matuyama magnetic reversal. At Site 711 very little carbonate is accumulating either before or after the Gauss/Matuyama magnetic reversal. More than $90 \%$ of the carbonate that settled through the water col-

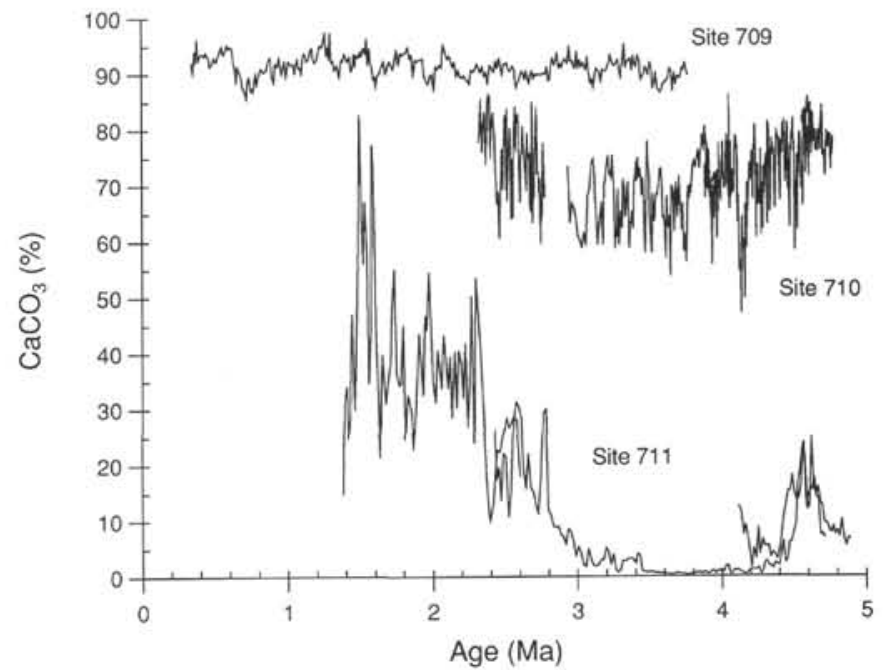

Figure 5. Time series of carbonate concentration for Sites 709, 710, and 711. The carbonate record for Site 709 exhibits low-frequency variations with a wave length of about $400 \mathrm{k} . \mathrm{y}$. In the deepest site (711), carbonate concentrations increase at about $2.8 \mathrm{Ma}$ and then very abruptly increase again at about $2.4 \mathrm{Ma}$. The abrupt increase at $2.4 \mathrm{Ma}$ correlates with the $\delta^{18} \mathrm{O}$ increase that marks the beginning of the latest phase of ice growth in the Northern Hemisphere (Shackleton et al., 1984). The earlier increase in concentration may correlate with the earlier $\delta^{18} \mathrm{O}$ increase observed by Keigwin (1986). The chronology is not accurate enough to be certain of this correlation.

umn to the seafloor has subsequently dissolved. Site 711 is the only site to exhibit an increase in carbonate accumulation across the Gauss/Matuyama magnetic reversal, increasing from 0 to $0.02 \mathrm{~g} / \mathrm{cm}^{2} / \mathrm{k}$.y. at $2.8 \mathrm{Ma}$ and from 0.02 to $0.06 \mathrm{~g} / \mathrm{cm}^{2} / \mathrm{k}$.y. at $2.4 \mathrm{Ma}$.

Noncarbonate accumulation was low in all three sites. In the shallowest hole, noncarbonate accumulation averaged $0.08 \mathrm{~g} /$ $\mathrm{cm}^{2} / \mathrm{k}$.y. before $2.47 \mathrm{Ma}$ and $0.06 \mathrm{~g} / \mathrm{cm}^{2} / \mathrm{k}$.y. after $2.47 \mathrm{Ma}$. In Site 710 a decrease also occurred, from values of $0.17 \mathrm{~g} / \mathrm{cm}^{2} /$ k.y. before $2.47 \mathrm{Ma}$ to $0.10 \mathrm{~g} / \mathrm{cm}^{2} / \mathrm{k}$.y. after $2.47 \mathrm{Ma}$. In the deepest site, low values of $0.11 \mathrm{~g} / \mathrm{cm}^{2} / \mathrm{k}$.y. occurred before and after the Gauss/Matuyama magnetic reversal. The slight bathymetric increase in noncarbonate accumulation implies that downslope reworking or advection of sediment components may have affected these sites. In a region with no lateral input of sediment, the refractory noncarbonate material should not exhibit any change in accumulation as a function of water depth (Curry and Lohmann, 1986). In these sites, noncarbonate accumulation increases slightly with depth in the water column after 2.47 Ma. Before $2.47 \mathrm{Ma}$, little difference in accumulation occurred between the shallowest and deepest site, but the middle site (710) had nearly twice the accumulation of noncarbonate material. It is difficult to evaluate the significance of these changes in noncarbonate accumulation because the values are so low in all cases. To quantify the extent of downslope or lateral input of material, it is necessary to measure the carbonate and noncarbonate accumulation rates in the smaller size fractions, as they are the sizes most likely to be affected by resuspension and redeposition (Curry and Lohmann, 1986). However, the existence of an increase in noncarbonate accumulation with depth in the water column cautions us to be concerned that carbonate may also have been transported into the deeper sites at this location by processes other than vertical settling. Therefore, our estimates of carbonate lost to dissolution should be considered "minima." 
Site $709(1.66-2.47 \mathrm{Ma})$

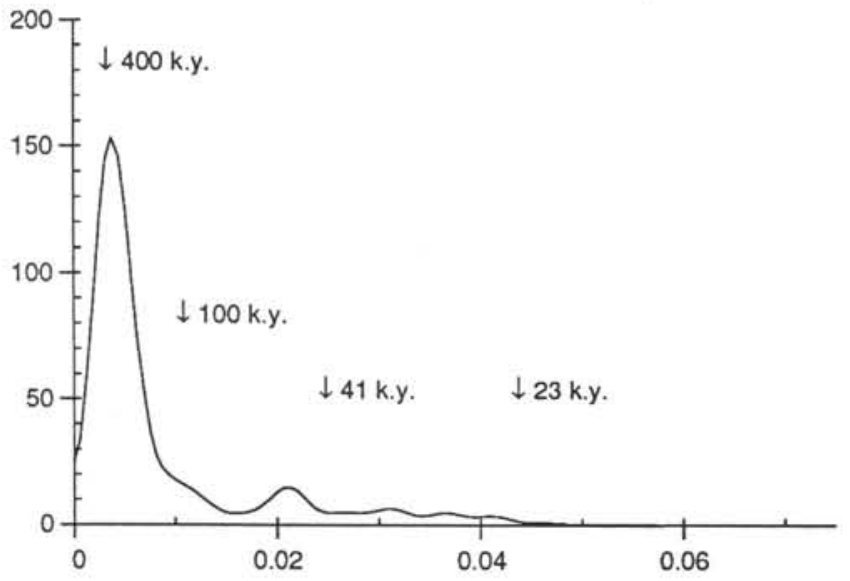

Site $711(1.66-2.47 \mathrm{Ma})$

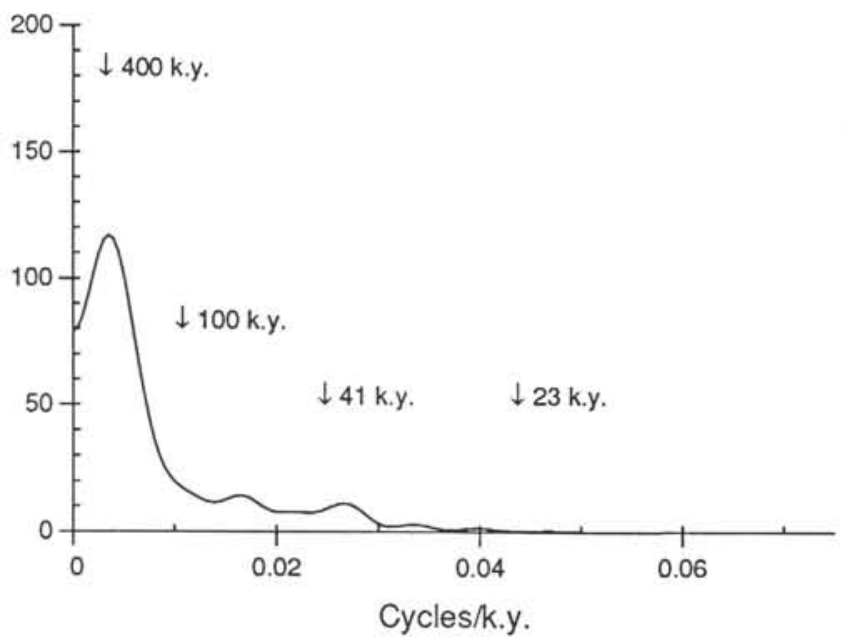

Site $709(2.47-3.40 \mathrm{Ma})$

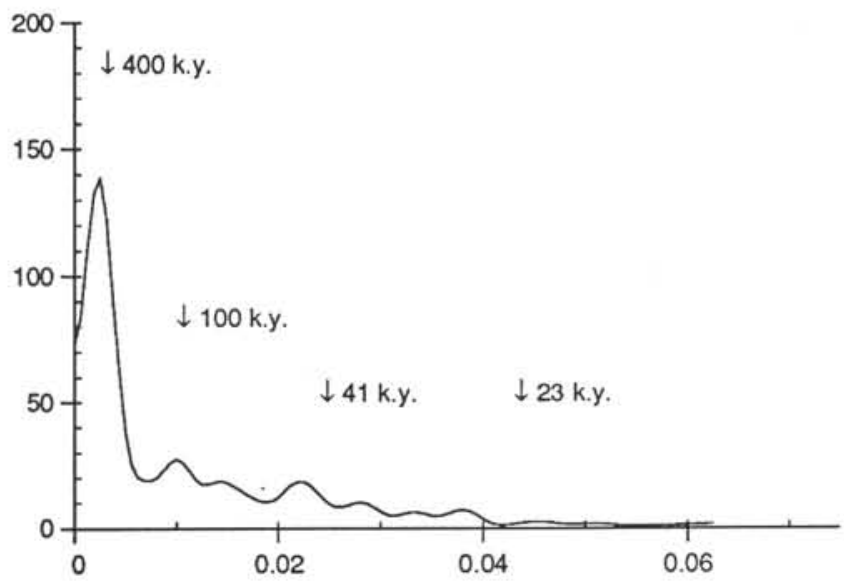

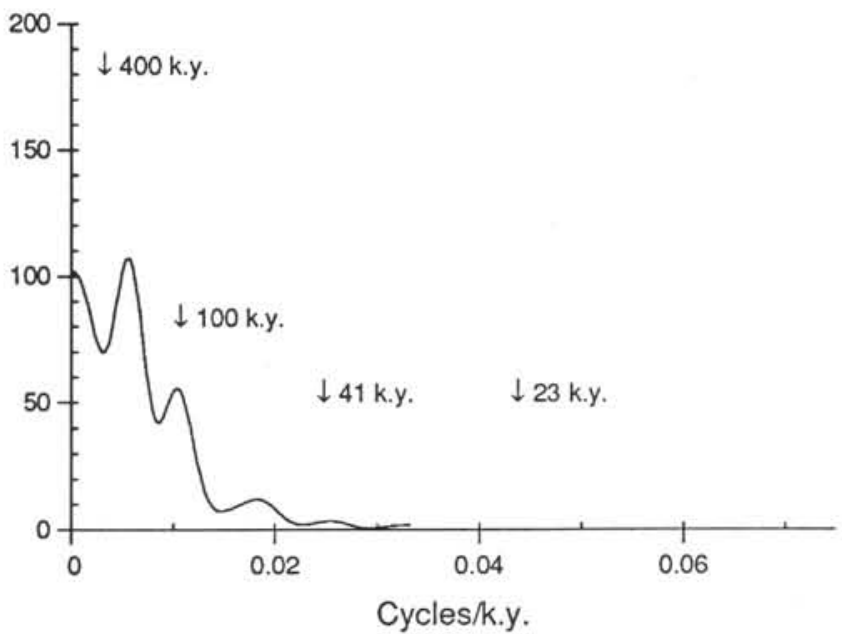

Figure 6. Spectral analysis of Sites 709 and 711 . Note that most of the power in these records is concentrated at low frequency. Before $2.47 \mathrm{Ma}$, Sites 709 and 710 (not shown) each exhibit a strong 400 k.y. period and a minor 100 k.y. period. Site 711 also has power at about 100 k.y., but no power at 400 k.y. After $2.47 \mathrm{Ma}$, Sites 709 and 711 each exhibit a strong 260-280-k.y. period. No 100 k.y. period is apparent in any of the sites after 2.47 Ma.

\section{DISCUSSION}

\section{History of Carbonate Productivity}

In Site 709 , the carbonate accumulation rate decreased by $\sim 0.1 \mathrm{~g} / \mathrm{cm}^{2} / \mathrm{k}$.y. after the Gauss/Matuyama magnetic reversal. This change in accumulation, if not caused by any change in carbonate dissolution, reflects a decrease in the production of carbonate in the overlying surface water. Dissolution changes have affected the sediments at this site (Cullen, this volume), but fortunately dissolution decreased after the magnetic reversal. Before $2.47 \mathrm{Ma}$, the ratio of foraminifer test fragments to whole tests was high, indicating that dissolution may have caused at least some loss of carbonate (Cullen, this volume). (Significant fragmentation of foraminifers can occur without measurable loss of $\mathrm{CaCO}_{3}$; Peterson and Prell, 1985b.) Therefore, the carbonate accumulation measured in Hole $709 \mathrm{~B}$ before $2.47 \mathrm{Ma}$ is a minimum estimate of the carbonate productivity rate in the surface waters at that time. After $2.47 \mathrm{Ma}$, dissolution (measured as the fragmentation ratio) and carbonate accumulation decreased, so the decrease in accumulation was not caused by changes in dissolution. Thus, we are confident that a decrease in productivity occurred at about $2.47 \mathrm{Ma}$ and that $\sim 0.1 \mathrm{~g} /$ $\mathrm{cm}^{2} / \mathrm{k}$.y. (the difference between the pre- and post-2.47 Ma values) is a minimum estimate of the decrease.

Throughout the Pliocene, Site 710 always had a lower carbonate accumulation than Site 709 (by $0.3 \mathrm{~g} / \mathrm{cm}^{2} / \mathrm{k}$.y.). Thus, dissolution must have influenced the accumulation rate of carbonate at Site 710 . Its carbonate accumulation also decreased by $\sim 0.1 \mathrm{~g} / \mathrm{cm}^{2} / \mathrm{k}$.y. after the Gauss/Matuyama magnetic reversal, the same difference observed in Site 709. This decrease in accumulation may have resulted from the same decrease in surface-water productivity implied by the record of Site 709 , but unfortunately our conclusion is ambiguous for two reasons. First, we have less confidence in our mean value for the 1.662.47-Ma interval because we sampled only a small number of sediments from just above the Gauss/Matuyama magnetic reversal. Second, we have no independent control over the changes in dissolution at this depth. We think that the dissolution rate 


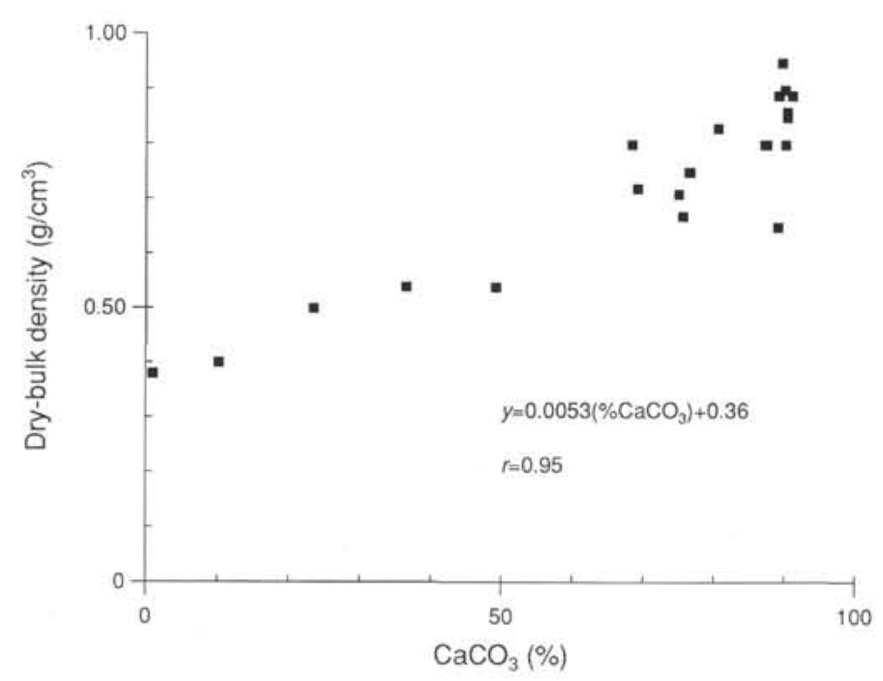

Figure 7. Dry-bulk density and carbonate concentration from shipboard measurements that were performed during Leg 115. The relationship between carbonate concentration and dry-bulk density is similar to the relationships that are observed in other equatorial locations where biogenic opal is the principal noncarbonate component of the sediment (Lyle and Dymond, 1976; Curry and Lohmann, 1985). Based on this strong correlation, we have used the carbonate concentration data to predict sediment bulk density in all of our accumulation rate calculations.

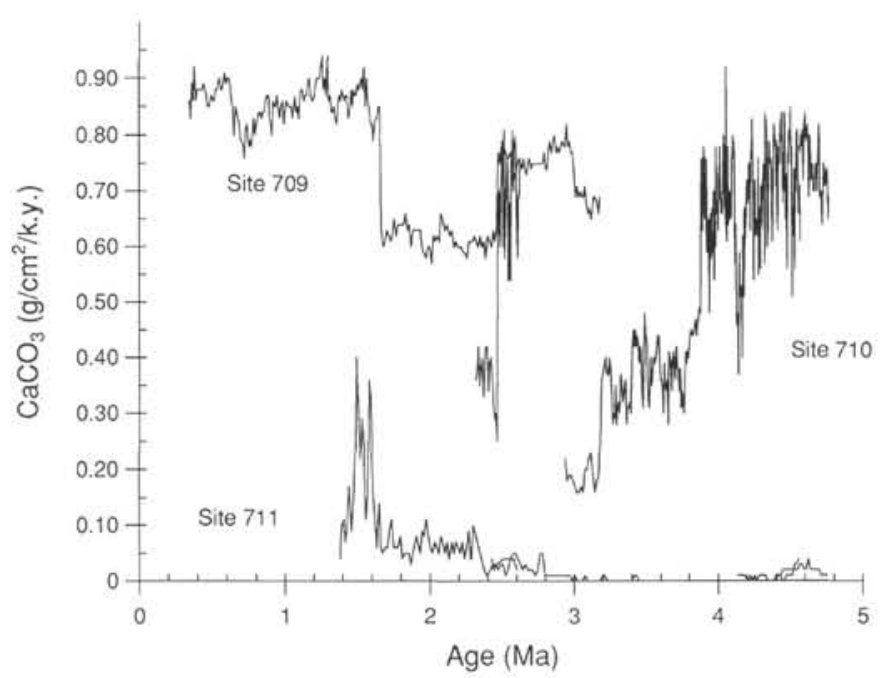

Figure 8. Carbonate accumulation rate variations for Sites 709, 710, and 711. Carbonate accumulation in Site 709 decreased on average by about $0.1 \mathrm{~g} / \mathrm{cm}^{2} / \mathrm{k} . \mathrm{y}$. at the Gauss/Matuyama magnetic reversal (2.47 Ma). At the same time, accumulation in the deepest site (711) increased. This pattern of carbonate accumulation implies that, in the Indian Ocean, carbonate productivity decreased at $2.47 \mathrm{Ma}$ while dissolution on the seafloor decreased. Parallel decreases in carbonate accumulation in Pliocene sediments of the Atlantic and Pacific oceans suggest that carbonate productivity may have decreased in many tropical locations at this time. A mean decrease in carbonate productivity, if it is not accompanied by a change in river input of $\mathrm{Ca}$ and $\mathrm{CO}_{3}$, would decrease the corrosiveness of deep water and increase carbonate preservation on the seafloor.
Table 1. Calculated accumulation rates of $\mathrm{CaCO}_{3}$ and non- $\mathrm{CaCO}_{3}$ for Sites 709, 710, and 711 .

\begin{tabular}{cccccccc}
\hline & \multicolumn{3}{c}{$1.66-2.47 \mathrm{Ma}$} & & \multicolumn{3}{c}{$2.47-3.40 \mathrm{Ma}$} \\
\cline { 2 - 3 } \cline { 6 - 8 } Site & $\mathrm{CaCO}_{3}$ & non- $\mathrm{CaCO}_{3}$ & $\#$ & & $\mathrm{CaCO}_{3}$ & non- $\mathrm{CaCO}_{3}$ & $\#$ \\
\hline 709 & $0.62 \pm 0.02$ & $0.06 \pm 0.01$ & $N=63$ & & $0.74 \pm 0.04$ & $0.08 \pm 0.01$ & $N=68$ \\
710 & $0.36 \pm 0.05$ & $0.10 \pm 0.03$ & $N=18$ & & $0.46 \pm 0.22$ & $0.17 \pm 0.06$ & $N=87$ \\
711 & $0.06 \pm 0.02$ & $0.11 \pm 0.01$ & $N=53$ & & $0.02 \pm 0.02$ & $0.11 \pm 0.01$ & $N=62$ \\
\hline
\end{tabular}

Note: The data are presented as averages (in $\mathrm{g} / \mathrm{cm}^{2} / \mathrm{k}$.y.) for the intervals between the Oldavai $(T)$ and the Gauss/Matuyama magnetic reversals (1.66-2.47 Ma) and the Gauss/Matuyama and Gauss/Gilbert (2.47-3.40 Ma) magnetic reversals.

did not increase since dissolution decreased in Site 709 (Cullen, this volume) and because we observe an increase in preservation in deeper Site 711.

\section{History of Carbonate Dissolution}

Of the three sites, only Site 711 experienced an increase in carbonate accumulation after the Gauss/Matuyama magnetic reversal. Although the increase is small, it is significant $(p<$ 0.005 ) because of the large number of analyses that have been used to produce the mean values. Because the accumulation rate in the two shallower sites decreased after the magnetic reversal, Site 711 also probably experienced a decreased input rate of carbonate because of lower surface-water productivity after 2.47 Ma. Thus, the increase in carbonate accumulation in Site 711 after $2.47 \mathrm{Ma}$ must have resulted from an increase in the preservation of calcium carbonate. (Changes in advection or downslope reworking of carbonate are not likely the cause of the increase in carbonate accumulation because the accumulation rate of the insoluble fraction in Site 711 is the same before and after 2.47 Ma.)

Carbonate preservation in the deep sea is controlled by processes that may act on the ocean as a whole (e.g., changes in surface-water productivity) or locally (changes in the location, chemistry, or production rate of deep water). To determine the cause of this change in preservation in Site 711, we must compare the changes in carbonate sedimentation at this location to those observed in the tropical Pacific and Atlantic oceans. For the Pacific, carbonate concentration data of comparable temporal resolution and shallow depth are available from Site 503 $\left(4^{\circ} 3^{\prime} \mathrm{N}, 95^{\circ} 38^{\prime} \mathrm{W}, 3672 \mathrm{~m}\right.$ water depth), and for the Atlantic (Caribbean), data are available from Site $502\left(11^{\circ} 29^{\prime} \mathrm{N}, 79^{\circ} 23^{\prime} \mathrm{W}\right.$, 3051-m water depth). We used the carbonate data from these sites (Prell, Gardner, et al., 1982) to determine if there were global changes in carbonate accumulation that may be related to changes in carbonate production.

Table 2 summarizes the changes in carbonate accumulation in the Atlantic (Site 502) and Pacific (Site 503) oceans that occurred at the Gauss/Matuyama magnetic reversal. Carbonate accumulation decreased in both sites at this time. In the Atlantic location, carbonate accumulation decreased from pre- 2.47 Ma values of $1.76 \mathrm{~g} / \mathrm{cm}^{2} / \mathrm{k} . \mathrm{y}$. to post- $2.47 \mathrm{Ma}$ values of $1.66 \mathrm{~g} /$ $\mathrm{cm}^{2} / \mathrm{k}$.y. In the Pacific Ocean location, carbonate accumulation decreased from 0.59 to $0.53 \mathrm{~g} / \mathrm{cm}^{2} / \mathrm{k}$.y. These decreases in accumulation occur at water depths that are above the present depth of the carbonate lysocline. The decreases in accumulation observed in Sites 502 and 503 are on the same order $\left(\sim 0.1 \mathrm{~g} / \mathrm{cm}^{2} /\right.$ k.y.) as the decrease observed in Site 709. Taken together, these data imply that the production rate of carbonate in the surface waters of tropical locations decreased near the Gauss/Matuyama magnetic reversal, in response to the cooling associated with Northern Hemisphere ice growth. Although the decrease in average productivity rate is clearly evident, the exact timing of the decrease is unconstrained by these data; our accumulation rates are forced to change at the magnetic reversal because the 
Table 2. Calculated accumulation rates of $\mathrm{CaCO}_{3}$ for Sites 502 (Atlantic) and 503 (Pacific).

\begin{tabular}{ccc}
\hline Site & $\begin{array}{c}1.66-2.47 \\
\mathrm{Ma}\end{array}$ & $\begin{array}{c}2.47-3.40 \\
\mathrm{Ma}\end{array}$ \\
\hline 502 & 1.66 & 1.76 \\
503 & 0.53 & 0.59 \\
\hline
\end{tabular}

Note: The carbonate data used in the calculations are from Prell, Gardner, et al. (1982). The data are presented as averages (in $\mathrm{g} / \mathrm{cm}^{2} / \mathrm{k}$.y.) for the intervals between the Olduvai (T) and Gauss/Matuyama magnetic reversals (1.66$2.47 \mathrm{Ma}$ ) and the Gauss/ Matuyama and Gauss/ Gilbert $(2.47-3.40 \mathrm{Ma})$

magnetic reversals.

reversal provides our sedimentation rate constraint. But on the basis of the effect of the decrease on carbonate productivity on preservation at the deepest site, we think that productivity may have changed in two steps, one at $2.8 \mathrm{Ma}$ and one at $2.4 \mathrm{Ma}$.

The increases in carbonate accumulation observed at this time in the deepest Indian Ocean site (711) most likely resulted from a decrease in carbonate productivity of the tropical oceans. In today's ocean, carbonate productivity far exceeds the rate of carbonate burial that is needed to balance the river input of calcium and carbonate. Consequently, only about a third of the carbonate produced in surface water survives chemical destruction on the shallow flanks of submarine rises and ridges. If the rate of productivity decreased without any net change in river input, the lysocline and carbonate compensation depth (CCD) must migrate to deeper locations if the balance of carbonate and calcium in the deep ocean is to be maintained. We think that the evidence presented here supports our hypothesis to explain the pattern of carbonate accumulation in Site 709,710 , and 711: a decrease in carbonate productivity of surface waters lowered the demand for carbonate dissolution needed to balance river input. Consequently, the dissolution rate decreased in Site 711 , which in turn increased its carbonate concentration and carbonate accumulation rate.

\section{CONCLUSIONS}

Carbonate sedimentation patterns changed near the Gauss/ Matuyama magnetic reversal in response to the major change in the earth's climate at that time. Based on these changing patterns, we conclude:

1. Surface-water productivity of carbonate-producing organisms decreased by about $0.1 \mathrm{~g} / \mathrm{cm}^{2} / \mathrm{k}$.y. in the western tropical Indian Ocean. Based on data from shallow APC sites in the tropical Atlantic and Pacific oceans, carbonate accumulation also decreased. If these sites were shallower than the carbonate lysocline at that time, then the evidence indicates that carbonate productivity may have decreased in all tropical regions of the oceans.

2. Dissolution decreased in the deepest parts of the western Indian Ocean, which caused increased carbonate concentration and accumulation in Site 711 after the Gauss/Matuyama magnetic reversal. This decrease in dissolution may have been a consequence of a decrease in carbonate productivity in the tropical Atlantic, Indian, and Pacific oceans.
3. Before $2.47 \mathrm{Ma}$, low-frequency variations with a period of 400 k.y. dominated the records of carbonate concentration. After 2.47, the low-frequency periodic component was closer to 280 k.y. in duration. Before $2.47 \mathrm{Ma}$, all sites exhibit variations in carbonate concentrations with a wave length of about $100 \mathrm{k} . \mathrm{y}$. These wave lengths are characteristic of eccentricity variations in the earth's orbit, implying that orbital variations affected the carbonate system during the early Pliocene.

\section{ACKNOWLEDGMENTS}

The carbonate data presented in this paper were produced by D. R. Ostermann. This paper benefited from reviews by two anonymous reviewers. We thank them for many useful comments. Although not supported by a specific grant, the research strategy used in this paper was developed through grants from the National Science Foundation. This is Woods Hole Oceanographic Institution Contribution No. 7397.

\section{REFERENCES}

Curry, W. B., and Lohmann, G. P., 1983. Reduced advection into Atlantic Ocean deep eastern basins during last glaciation maximum. Nature, 306:577-580.

1985. Carbon deposition rates and deep water residence time in the equatorial Atlantic Ocean throughout the last 160,000 years. In Sundquist, E. T., and Broecker, W. S. (Ed.), The Carbon Cycle and Atmospheric $\mathrm{CO}_{2}:$ Natural Variations Archean to Present. Am. Geophys. Union Monogr., 32:285-301.

1986. Late Quaternary carbonate sedimentation at the Sierra Leone Rise (eastern equatorial Atlantic Ocean). Mar. Geol., 70:223250 .

in press. Reconstructing past particle fluxes in the tropical Atlantic Ocean. Paleoceanography.

Johnson, D. A., Ledbetter, M., and Burckle, L. H., 1977. Vema Channel paleo-oceanography: Pleistocene dissolution cycles and episodic bottom water flow. Mar. Geol., 23:1-33.

Keigwin, L. D., 1986. Pliocene stable-isotope record of Deep Sea Drilling Project Site 606: sequential events of ${ }^{18} \mathrm{O}$ enrichment beginning at 3.1 Ma. In Ruddiman, W. F., Kidd, R. B., Thomas, E., et al., Init. Repts. DSDP, 94, Pt. 2: Washington (U.S. Govt. Printing Office), 911-920.

Lyle, M. W., and Dymond, J., 1976. Metal accumulation rates in the southeast Pacific-errors introduced from assumed bulk densities. Earth Planet. Sci. Lett., 30:164-168.

Ostermann, D. R., Karbott, D., and Curry, W. B., 1990. Automated system to measure the carbonate concentration of sediments. Woods Hole Oceanogr. Inst. Tech. Rep. WHOI-90-03.

Peterson, L. C., and Prell, W. L., 1985a. Carbonate preservation and rates of climatic change: an $800 \mathrm{kyr}$ record from the Indian Ocean. In Sundquist, E. T., and Broecker, W. S. (Ed.), The Carbon Cycle and Atmospheric $\mathrm{CO}_{2}:$ Natural Variations Archean to Present. Am. Geophys. Union Monogr., 32:251-269.

1985b. Carbonate dissolution in Recent sediments of the eastern equatorial Indian Ocean: preservation patterns and carbonate loss above the lysocline. Mar. Geol., 64:259-290.

Pisias, N. G., and Prell, W. L., 1985. High resolution carbonate records from the hydraulic piston cored section of Site 572. In Mayer, L., Theyer, F., Thomas, E., et al., Init. Repts. DSDP, 85: Washington (U.S. Govt. Printing Office), 711-722.

Prell, W. L., Gardner, J. V., et al., 1982. Init. Repts. DSDP, 68: Washington (U.S. Govt. Printing Office).

Shackleton, N. J., Backman, J., Zimmerman, H. B., Kent, D. V., Hall, M. A., Roberts, D. G., Schnitker, D., Baldauf, J. G., Desprairies, A., Homrighausen, R., Huddleston, P., Keene, J. B., Kaltenback, A. J., Krumsiek, K.A.O. Morton, A.C., Murray, J. W., and Westberg-Smith, J., 1984. Oxygen isotope calibration of the onset of icerafting in DSDP Site 552A: history of glaciation in the North Atlantic region. Nature, 307:620-623.

Date of initial receipt: 11 September 1989

Date of acceptance: 22 January 1990

Ms 115B-164 
APPENDIX

Carbonate Concentrations for Sites 709, 710, and 711 .

\begin{tabular}{|c|c|c|c|c|c|c|c|c|c|c|c|c|c|c|}
\hline $\begin{array}{l}\text { Depth } \\
\text { (msbf) }\end{array}$ & $\begin{array}{c}\text { Age } \\
\text { (Ma) }\end{array}$ & $\begin{array}{c}\mathrm{CaCO}_{3} \\
(\%)\end{array}$ & $\begin{array}{l}\text { Depth } \\
\text { (msbf) }\end{array}$ & $\begin{array}{l}\text { Age } \\
(\mathrm{Ma})\end{array}$ & $\begin{array}{c}\mathrm{CaCO}_{3} \\
(\%)\end{array}$ & $\begin{array}{l}\text { Depth } \\
\text { (msbf) }\end{array}$ & $\begin{array}{l}\text { Age } \\
\text { (Ma) }\end{array}$ & $\begin{array}{c}\mathrm{CaCO}_{3} \\
(\%)\end{array}$ & $\begin{array}{l}\text { Depth } \\
\text { (msbf) }\end{array}$ & $\begin{array}{l}\text { Age } \\
(\mathrm{Ma})\end{array}$ & $\begin{array}{c}\mathrm{CaCO}_{3} \\
(\%)\end{array}$ & $\begin{array}{l}\text { Depth } \\
\text { (msbf) }\end{array}$ & $\begin{array}{l}\text { Age } \\
(\mathrm{Ma})\end{array}$ & $\begin{array}{c}\mathrm{CaCO}_{3} \\
(\%)\end{array}$ \\
\hline \multicolumn{3}{|c|}{$115-709 \mathrm{~B}-2 \mathrm{H}-$} & \multicolumn{3}{|c|}{ 115-709B-2H- (Cont.) } & \multicolumn{3}{|c|}{ 115-709B-2H- (Cont.) } & $115-709 \mathrm{~B}-2$ & - (Cont & & $115-709 \mathrm{~B}-2 \mathrm{H}$ & I- (Cont.) & \\
\hline 3.84 & 0.345 & 92.1 & 11.44 & 1.027 & 91.6 & 18.94 & 1.717 & 91.8 & 28.95 & 2.897 & 91.1 & 36.54 & 3.696 & 89.6 \\
\hline 3.94 & 0.354 & 89.9 & 11.54 & 1.035 & 91.8 & 19.04 & 1.729 & 90.8 & 29.05 & 2.908 & 92.2 & 36.64 & 3.707 & 89.3 \\
\hline 4.04 & 0.363 & 94.0 & 11.64 & 1.044 & 91.8 & 19.12 & 1.740 & 92.1 & 29.14 & 2.917 & 92.7 & 36.74 & 3.717 & 89.3 \\
\hline 4.14 & 0.371 & 92.1 & 11.74 & 1.053 & 90.1 & 19.22 & 1.753 & 94.5 & 29.34 & 2.937 & 91.8 & 36.84 & 3.728 & 91.1 \\
\hline 4.24 & 0.380 & 96.3 & 11.84 & 1.062 & 91.7 & 19.34 & 1.768 & 91.6 & 29.44 & 2.948 & 95.0 & 36.94 & 3.738 & 90.5 \\
\hline 4.34 & 0.389 & 92.3 & 11.94 & 1.071 & 92.8 & 19.44 & 1.781 & 93.8 & 29.54 & 2.958 & 92.2 & 37.04 & 3.749 & 92.0 \\
\hline 4.44 & 0.398 & 93.2 & 12.04 & 1.080 & 91.0 & 19.54 & 1.794 & 93.4 & 29.64 & 2.968 & 92.4 & 37.14 & 3.760 & 90.7 \\
\hline 4.54 & 0.407 & 93.6 & 12.14 & 1.089 & 91.2 & 19.64 & 1.807 & 93.8 & 29.74 & 2.979 & 91.3 & 37.24 & 3.770 & 89.7 \\
\hline 4.64 & 0.416 & 93.7 & 12.24 & 1.098 & 89.8 & 19.74 & 1.819 & 93.9 & 29.84 & 2.989 & 90.9 & & & \\
\hline 4.74 & 0.425 & 93.4 & 12.34 & 1.107 & 92.5 & 19.84 & 1.832 & 94.9 & 29.94 & 3.000 & 94.0 & $115-710 \mathrm{~A}-3 \mathrm{H}$ & & \\
\hline 4.83 & 0.433 & 93.2 & 12.42 & 1.114 & 93.7 & 19.94 & 1.845 & 92.8 & 30.04 & 3.010 & 90.9 & & & \\
\hline 4.92 & 0.441 & 94.0 & 12.53 & 1.124 & 93.7 & 20.04 & 1.858 & 93.6 & 30.13 & 3.020 & 92.5 & 19.21 & 2.317 & 77.7 \\
\hline 5.04 & 0.452 & 93.2 & 12.63 & 1.133 & 92.3 & 20.14 & 1.871 & 89.5 & 30.24 & 3.031 & 91.1 & 19.26 & 2.325 & 80.0 \\
\hline 5.14 & 0.461 & 93.1 & 12.73 & 1.142 & 92.6 & 20.24 & 1.884 & 92.6 & 30.36 & 3.044 & 92.0 & 19.31 & 2.334 & 85.6 \\
\hline 5.24 & 0.470 & 91.3 & 12.84 & 1.152 & 93.1 & 20.34 & 1.897 & 92.3 & 30.44 & 3.052 & 91.4 & 19.36 & 2.342 & 76.1 \\
\hline 5.34 & 0.479 & 91.7 & 12.94 & 1.161 & 94.3 & 20.44 & 1.909 & 92.6 & 30.54 & 3.063 & 90.6 & 19.41 & 2.351 & 81.1 \\
\hline 5.44 & 0.488 & 92.0 & 13.04 & 1.170 & 94.8 & 20.54 & 1.922 & 92.6 & 30.64 & 3.073 & 93.0 & 19.46 & 2.360 & 83.2 \\
\hline 5.54 & 0.497 & 93.0 & 13.14 & 1.179 & 92.8 & 20.64 & 1.935 & 92.8 & 30.74 & 3.084 & 90.1 & 19.52 & 2.370 & 73.8 \\
\hline 5.64 & 0.506 & 92.3 & 13.25 & 1.189 & 92.0 & 20.72 & 1.945 & 89.7 & 30.84 & 3.095 & 88.2 & 19.58 & 2.380 & 84.2 \\
\hline 5.74 & 0.515 & 92.2 & 13.33 & 1.196 & 92.3 & 20.81 & 1.957 & 89.0 & 30.94 & 3.105 & 89.1 & 19.61 & 2.386 & 86.4 \\
\hline 5.84 & 0.524 & 93.2 & 13.44 & 1.206 & 92.7 & 20.94 & 1.974 & 88.1 & 31.04 & 3.116 & 87.2 & 19.66 & 2.394 & 86.1 \\
\hline 5.94 & 0.533 & 93.7 & 13.54 & 1.215 & 94.1 & 21.04 & 1.987 & 89.7 & 31.14 & 3.126 & 89.6 & 19.71 & 2.403 & 75.0 \\
\hline 6.03 & 0.541 & 94.4 & 13.64 & 1.224 & 95.1 & 21.14 & 1.999 & 90.0 & 31.22 & 3.135 & 91.0 & 19.76 & 2.411 & 81.6 \\
\hline 6.14 & 0.551 & 95.1 & 13.74 & 1.233 & 94.8 & 21.24 & 2.012 & 87.0 & 31.32 & 3.145 & 90.6 & 19.81 & 2.420 & 83.1 \\
\hline 6.24 & 0.560 & 93.5 & 13.84 & 1.242 & 94.9 & 21.34 & 2.025 & 91.5 & 31.44 & 3.158 & 90.1 & 19.86 & 2.429 & 78.8 \\
\hline 6.33 & 0.568 & 93.7 & 13.94 & 1.251 & 96.1 & 21.44 & 2.038 & 90.8 & 31.54 & 3.168 & 88.3 & 19.91 & 2.437 & 72.7 \\
\hline 6.42 & 0.576 & 94.4 & 14.04 & 1.260 & 97.5 & 21.54 & 2.051 & 91.7 & 31.63 & 3.178 & 90.8 & 19.96 & 2.446 & 66.8 \\
\hline 6.54 & 0.587 & 95.3 & 14.14 & 1.269 & 93.3 & 21.66 & 2.066 & 91.1 & 31.74 & 3.190 & 90.4 & 20.01 & 2.454 & 68.7 \\
\hline 6.64 & 0.596 & 94.5 & 14.24 & 1.278 & 94.9 & 21.74 & 2.077 & 95.4 & 31.86 & 3.202 & 90.4 & 20.06 & 2.463 & 60.7 \\
\hline 6.74 & 0.605 & 94.9 & 14.34 & 1.287 & 92.6 & 21.84 & 2.089 & 94.2 & 31.96 & 3.213 & 91.3 & 20.11 & 2.471 & 69.8 \\
\hline 6.84 & 0.614 & 94.9 & 14.44 & 1.296 & 97.4 & 21.97 & 2.106 & 92.7 & 32.05 & 3.222 & 91.9 & 20.16 & 2.475 & 71.5 \\
\hline 6.94 & 0.623 & 94.4 & 14.53 & 1.304 & 92.0 & 22.07 & 2.119 & 93.3 & 32.14 & 3.232 & 93.4 & 20.21 & 2.479 & 76.5 \\
\hline 7.04 & 0.632 & 92.0 & 14.65 & 1.315 & 92.5 & 22.15 & 2.129 & 92.5 & 32.24 & 3.242 & 92.2 & 20.27 & 2.485 & 73.9 \\
\hline 7.14 & 0.641 & 91.3 & 14.75 & 1.324 & 90.6 & 22.24 & 2.141 & 91.3 & 32.34 & 3.253 & 91.4 & 20.31 & 2.488 & 69.3 \\
\hline 7.24 & 0.650 & 88.3 & 14.85 & 1.332 & 91.1 & 22.34 & 2.154 & 92.2 & 32.44 & 3.263 & 91.5 & 20.37 & 2.493 & 77.1 \\
\hline 7.34 & 0.659 & 91.5 & 14.94 & 1.341 & 91.6 & 22.44 & 2.167 & 89.5 & 32.54 & 3.274 & 91.9 & 20.40 & 2.496 & 78.6 \\
\hline 7.44 & 0.668 & 90.7 & 15.04 & 1.350 & 90.4 & 22.54 & 2.179 & 90.8 & 32.64 & 3.285 & 92.5 & 20.46 & 2.501 & 82.3 \\
\hline 7.54 & 0.677 & 90.1 & 15.14 & 1.359 & 89.3 & 22.64 & 2.192 & 89.6 & 32.74 & 3.295 & 90.4 & 20.51 & 2.505 & 82.6 \\
\hline 7.64 & 0.686 & 89.2 & 15.24 & 1.367 & 91.7 & 22.74 & 2.205 & 89.3 & 32.85 & 3.307 & 89.0 & 20.56 & 2.509 & 69.3 \\
\hline 7.74 & 0.695 & 87.5 & 15.34 & 1.376 & 92.7 & 22.84 & 2.218 & 89.8 & 32.86 & 3.308 & 91.0 & 20.61 & 2.514 & 83.7 \\
\hline 7.84 & 0.703 & 87.5 & 15.44 & 1.385 & 92.2 & 22.94 & 2.231 & 89.1 & 32.94 & 3.316 & 91.8 & 20.66 & 2.518 & 67.4 \\
\hline 7.95 & 0.713 & 86.4 & 15.54 & 1.394 & 93.7 & 23.02 & 2.241 & 88.9 & 33.04 & 3.327 & 95.3 & 20.71 & 2.522 & 71.1 \\
\hline 8.04 & 0.721 & 85.4 & 15.64 & 1.403 & 93.1 & 23.14 & 2.257 & 88.2 & 33.14 & 3.337 & 91.1 & 20.76 & 2.527 & 75.9 \\
\hline 8.12 & 0.729 & 88.9 & 15.74 & 1.412 & 92.2 & 23.24 & 2.269 & 90.8 & 33.24 & 3.348 & 92.2 & 20.81 & 2.531 & 78.0 \\
\hline 8.24 & 0.739 & 89.6 & 15.84 & 1.421 & 92.7 & 23.34 & 2.282 & 90.3 & 33.34 & 3.358 & 92.4 & 20.86 & 2.535 & 80.2 \\
\hline 8.38 & 0.752 & 86.9 & 15.94 & 1.430 & 93.1 & 23.44 & 2.295 & 90.8 & 33.44 & 3.369 & 92.7 & 20.91 & 2.539 & 78.9 \\
\hline 8.46 & 0.759 & 87.5 & 16.04 & 1.439 & 90.4 & 23.54 & 2.308 & 91.9 & 33.54 & 3.380 & 90.6 & 20.96 & 2.544 & 64.0 \\
\hline 8.55 & 0.767 & 86.7 & 16.18 & 1.452 & 91.3 & 23.64 & 2.321 & 91.0 & 33.64 & 3.390 & 93.2 & 21.02 & 2.549 & 65.8 \\
\hline 8.64 & 0.775 & 88.3 & 16.26 & 1.459 & 93.6 & 23.74 & 2.334 & 90.2 & 33.74 & 3.401 & 91.6 & 21.08 & 2.554 & 74.7 \\
\hline 8.74 & 0.784 & 90.3 & 16.36 & 1.468 & 91.4 & 23.84 & 2.347 & 91.4 & 33.83 & 3.410 & 91.1 & 21.11 & 2.557 & 64.3 \\
\hline 8.84 & 0.793 & 88.0 & 16.44 & 1.475 & 93.5 & 23.94 & 2.359 & 89.5 & 33.92 & 3.420 & 93.3 & 21.16 & 2.561 & 75.4 \\
\hline 8.94 & 0.802 & 89.6 & 16.54 & 1.484 & 93.1 & 24.04 & 2.372 & 90.4 & 34.04 & 3.432 & 92.6 & 21.21 & 2.565 & 81.5 \\
\hline 9.04 & 0.811 & 90.2 & 16.64 & 1.493 & 92.9 & 24.13 & 2.384 & 88.2 & 34.14 & 3.443 & 88.7 & 21.26 & 2.569 & 81.0 \\
\hline 9.14 & 0.820 & 91.1 & 16.74 & 1.502 & 94.0 & 24.25 & 2.399 & 91.6 & 34.24 & 3.453 & 89.6 & 21.31 & 2.574 & 84.1 \\
\hline 9.25 & 0.830 & 90.7 & 16.84 & 1.511 & 93.2 & 24.36 & 2.413 & 91.0 & 34.34 & 3.464 & 89.7 & 21.36 & 2.578 & 76.0 \\
\hline 9.35 & 0.839 & 90.3 & 16.94 & 1.520 & 94.4 & 24.46 & 2.426 & 90.2 & 34.44 & 3.475 & 91.2 & 21.41 & 2.582 & 82.5 \\
\hline 9.46 & 0.849 & 90.6 & 17.04 & 1.529 & 94.7 & 24.56 & 2.439 & 92.4 & 34.54 & 3.485 & 90.7 & 21.46 & 2.587 & 82.0 \\
\hline 9.55 & 0.857 & 90.6 & 17.14 & 1.538 & 93.6 & 24.64 & 2.449 & 91.0 & 34.64 & 3.496 & 89.7 & 21.51 & 2.591 & 82.9 \\
\hline 9.66 & 0.867 & 91.9 & 17.24 & 1.547 & 96.4 & 24.74 & 2.462 & 92.9 & 34.74 & 3.506 & 92.1 & 21.56 & 2.595 & 81.0 \\
\hline 9.76 & 0.876 & 92.7 & 17.34 & 1.556 & 91.6 & 24.84 & 2.474 & 91.2 & 34.84 & 3.517 & 91.0 & 21.61 & 2.599 & 73.5 \\
\hline 9.88 & 0.887 & 93.1 & 17.44 & 1.565 & 94.6 & 24.94 & 2.484 & 89.7 & 34.94 & 3.527 & 87.3 & 21.66 & 2.604 & 70.1 \\
\hline 9.96 & 0.894 & 90.0 & 17.54 & 1.574 & 92.2 & 25.04 & 2.495 & 91.8 & 35.04 & 3.538 & 88.1 & 21.71 & 2.608 & 67.1 \\
\hline 10.05 & 0.902 & 89.1 & 17.67 & 1.586 & 91.0 & 25.14 & 2.505 & 91.8 & 35.14 & 3.548 & 90.2 & 21.77 & 2.613 & 75.3 \\
\hline 10.14 & 0.910 & 88.3 & 17.76 & 1.594 & 89.1 & 25.24 & 2.515 & 92.1 & 35.24 & 3.559 & 87.3 & 21.81 & 2.617 & 75.5 \\
\hline 10.24 & 0.919 & 92.0 & 17.86 & 1.603 & 89.6 & 25.34 & 2.526 & 90.9 & 35.34 & 3.570 & 86.9 & 21.87 & 2.622 & 77.1 \\
\hline 10.35 & 0.929 & 91.3 & 17.94 & 1.610 & 87.4 & 27.94 & 2.793 & 91.3 & 35.43 & 3.579 & 86.6 & 21.90 & 2.624 & 80.6 \\
\hline 10.44 & 0.937 & 91.6 & 18.04 & 1.619 & 89.5 & 28.04 & 2.804 & 88.7 & 35.54 & 3.591 & 87.2 & 22.21 & 2.651 & 69.1 \\
\hline 10.54 & 0.946 & 93.1 & 18.14 & 1.628 & 89.9 & 28.14 & 2.814 & 89.0 & 35.64 & 3.601 & 88.4 & 22.26 & 2.655 & 79.3 \\
\hline 10.64 & 0.955 & 91.3 & 18.24 & 1.637 & 90.1 & 28.22 & 2.822 & 91.3 & 35.74 & 3.612 & 88.4 & 22.31 & 2.659 & 77.1 \\
\hline 10.74 & 0.964 & 89.9 & 18.34 & 1.646 & 91.2 & 28.32 & 2.832 & 92.9 & 35.94 & 3.633 & 89.2 & 22.36 & 2.664 & 75.5 \\
\hline 10.86 & 0.974 & 91.4 & 18.44 & 1.655 & 91.5 & 28.44 & 2.845 & 91.5 & 36.04 & 3.643 & 91.0 & 22.41 & 2.668 & 74.7 \\
\hline 10.97 & 0.984 & 92.4 & 18.54 & 1.665 & 92.5 & 28.54 & 2.855 & 92.6 & 36.14 & 3.654 & 90.5 & 22.46 & 2.672 & 75.7 \\
\hline 11.05 & 0.992 & 89.2 & 18.64 & 1.678 & 89.9 & 28.63 & 2.864 & 93.8 & 36.24 & 3.665 & 86.9 & 22.52 & 2.677 & 65.9 \\
\hline 11.16 & 1.001 & 90.9 & 18.74 & 1.691 & 91.1 & 28.75 & 2.877 & 90.9 & 36.34 & 3.675 & 90.2 & 22.58 & 2.683 & 65.3 \\
\hline 11.26 & 1.010 & 92.4 & 18.84 & 1.704 & 92.3 & 28.86 & 2.888 & 91.8 & 36.44 & 3.686 & 88.0 & 22.61 & 2.685 & 69.4 \\
\hline
\end{tabular}


Appendix (continued).

\begin{tabular}{|c|c|c|c|c|c|c|c|c|c|c|c|c|c|c|}
\hline $\begin{array}{l}\text { Depth } \\
\text { (msbf) }\end{array}$ & $\begin{array}{l}\text { Age } \\
(\mathrm{Ma})\end{array}$ & $\begin{array}{c}\mathrm{CaCO}_{3} \\
(\%)\end{array}$ & $\begin{array}{l}\text { Depth } \\
\text { (msbf) }\end{array}$ & $\begin{array}{l}\text { Age } \\
(\mathrm{Ma})\end{array}$ & $\begin{array}{c}\mathrm{CaCO}_{3} \\
(\%)\end{array}$ & $\begin{array}{l}\text { Depth } \\
\text { (msbf) }\end{array}$ & $\begin{array}{l}\text { Age } \\
(\mathrm{Ma})\end{array}$ & $\begin{array}{c}\mathrm{CaCO}_{3} \\
(\%)\end{array}$ & $\begin{array}{l}\text { Depth } \\
\text { (msbf) }\end{array}$ & $\begin{array}{l}\text { Age } \\
\text { (Ma) }\end{array}$ & $\begin{array}{c}\mathrm{CaCO}_{3} \\
(\%)\end{array}$ & $\begin{array}{l}\text { Depth } \\
\text { (msbf) }\end{array}$ & $\begin{array}{l}\text { Age } \\
\text { (Ma) }\end{array}$ & $\begin{array}{c}\mathrm{CaCO}_{3} \\
(\%)\end{array}$ \\
\hline $115-710 \mathrm{~A}-3 \mathrm{H}$ & - (Cont. & & $115-710 \mathrm{~A}-4 \mathrm{H}$ & [- (Cont.) & & $115-710 \mathrm{~A}-4 \mathrm{H}-$ & - (Cont.) & & $5-710 B-41$ & - (Cont.) & & $115-710 \mathrm{~B}-4 \mathrm{H}$ & (Cont. & \\
\hline 22.66 & 2.689 & 85.0 & 31.41 & 4.085 & 68.7 & 35.26 & 4.377 & 69.2 & 26.31 & 3.074 & 68.1 & 30.12 & 3.636 & 62.4 \\
\hline 22.71 & 2.694 & 63.3 & 31.47 & 4.089 & 69.3 & 35.31 & 4.381 & 77.2 & 26.36 & 3.088 & 69.5 & 30.16 & 3.641 & 64.5 \\
\hline 22.76 & 2.698 & 68.1 & 31.52 & 4.093 & 76.2 & 35.36 & 4.385 & 80.0 & 26.41 & 3.101 & 74.0 & 30.21 & 3.648 & 53.8 \\
\hline 22.81 & 2.702 & 67.9 & 31.56 & 4.096 & 76.6 & 35.41 & 4.388 & 78.8 & 26.46 & 3.115 & 74.9 & 30.26 & 3.654 & 69.9 \\
\hline 22.86 & 2.707 & 75.7 & 31.62 & 4.101 & 78.8 & 35.46 & 4.392 & 78.8 & 26.50 & 3.126 & 67.9 & 30.31 & 3.661 & 69.5 \\
\hline 22.91 & 2.711 & 76.9 & 31.67 & 4.104 & 78.4 & 35.52 & 4.397 & 78.0 & 26.56 & 3.142 & 59.5 & 30.36 & 3.667 & 68.1 \\
\hline 22.96 & 2.715 & 81.6 & 31.71 & 4.107 & 78.2 & 35.56 & 4.400 & 73.4 & 26.61 & 3.156 & 63.8 & 30.41 & 3.674 & 61.8 \\
\hline 23.01 & 2.719 & 84.0 & 31.76 & 4.111 & 75.7 & 35.61 & 4.404 & 78.5 & 26.66 & 3.169 & 66.9 & 30.46 & 3.680 & 68.7 \\
\hline 23.06 & 2.724 & 75.2 & 31.81 & 4.115 & 63.4 & 35.66 & 4.407 & 69.5 & 26.71 & 3.181 & 59.4 & 30.51 & 3.687 & 70.5 \\
\hline 23.11 & 2.728 & 72.0 & 31.86 & 4.119 & 68.1 & 35.71 & 4.411 & 67.4 & 26.76 & 3.188 & 70.1 & 30.56 & 3.693 & 65.5 \\
\hline 23.16 & 2.732 & 72.6 & 31.96 & 4.126 & 54.8 & 35.76 & 4.415 & 75.9 & 26.82 & 3.196 & 70.9 & 30.60 & 3.698 & 64.4 \\
\hline 23.21 & 2.737 & 68.8 & 32.01 & 4.130 & 56.5 & 35.81 & 4.419 & 78.0 & 26.86 & 3.202 & 73.0 & 30.66 & 3.706 & 71.6 \\
\hline 23.27 & 2.742 & 71.3 & 32.06 & 4.134 & 55.0 & 35.87 & 4.423 & 75.7 & 26.91 & 3.209 & 74.2 & 30.71 & 3.713 & 66.5 \\
\hline 23.31 & 2.745 & 69.6 & 32.12 & 4.139 & 47.2 & 35.91 & 4.426 & 79.3 & 26.96 & 3.216 & 75.3 & 30.76 & 3.719 & 66.3 \\
\hline 23.37 & 2.750 & 59.6 & 32.17 & 4.142 & 56.4 & 35.97 & 4.431 & 81.2 & 27.01 & 3.223 & 71.9 & 30.81 & 3.726 & 62.1 \\
\hline 23.40 & 2.753 & 63.8 & 32.21 & 4.145 & 64.3 & 36.02 & 4.435 & 78.4 & 27.06 & 3.230 & 72.6 & 30.86 & 3.732 & 66.8 \\
\hline 23.46 & 2.758 & 64.4 & 32.26 & 4.149 & 58.4 & 36.06 & 4.438 & 81.8 & 27.11 & 3.236 & 71.1 & 30.91 & 3.739 & 58.3 \\
\hline 23.51 & 2.762 & 71.0 & 32.31 & 4.153 & 60.4 & 36.12 & 4.442 & 76.0 & 27.16 & 3.243 & 75.3 & 30.96 & 3.745 & 61.4 \\
\hline 23.56 & 2.767 & 77.6 & 32.36 & 4.157 & 59.3 & 36.17 & 4.446 & 70.7 & 27.21 & 3.250 & 72.2 & 31.00 & 3.750 & 60.2 \\
\hline 23.61 & 2.771 & 73.9 & 32.41 & 4.161 & 58.7 & 36.21 & 4.449 & 74.4 & 27.26 & 3.257 & 68.0 & 31.06 & 3.758 & 56.3 \\
\hline 23.66 & 2.775 & 67.8 & 32.46 & 4.164 & 49.8 & 36.26 & 4.453 & 72.6 & 27.31 & 3.264 & 58.7 & 31.11 & 3.765 & 64.3 \\
\hline & & & 32.52 & 4.169 & 66.5 & 36.31 & 4.457 & 81.3 & 27.36 & 3.271 & 62.2 & 31.16 & 3.771 & 69.8 \\
\hline $115-710 \mathrm{~A}-4 \mathrm{H}$ & & & 32.56 & 4.172 & 59.3 & 36.36 & 4.461 & 80.5 & 27.41 & 3.278 & 60.8 & 31.21 & 3.778 & 67.7 \\
\hline & & & 32.61 & 4.176 & 58.9 & 36.41 & 4.464 & 69.2 & 27.46 & 3.284 & 69.3 & 31.26 & 3.784 & 70.0 \\
\hline 28.81 & 3.887 & 73.7 & 32.66 & 4.180 & 70.4 & 36.46 & 4.468 & 74.5 & 27.51 & 3.291 & 59.5 & 31.31 & 3.790 & 68.6 \\
\hline 28.86 & 3.891 & 67.8 & 32.71 & 4.183 & 65.4 & 36.51 & 4.472 & 68.0 & 27.56 & 3.298 & 63.3 & 31.36 & 3.797 & 71.3 \\
\hline 28.91 & 3.895 & 73.9 & 32.76 & 4.187 & 67.4 & 36.56 & 4.476 & 62.6 & 27.60 & 3.304 & 65.4 & 31.41 & 3.803 & 73.3 \\
\hline 28.96 & 3.899 & 78.0 & 32.81 & 4.191 & 69.7 & 36.62 & 4.480 & 76.9 & 27.66 & 3.312 & 62.4 & 31.46 & 3.810 & 74.6 \\
\hline 29.01 & 3.902 & 72.9 & 32.87 & 4.196 & 73.9 & 36.67 & 4.484 & 76.0 & 27.71 & 3.319 & 71.1 & 31.51 & 3.816 & 73.5 \\
\hline 29.06 & 3.906 & 69.2 & 32.91 & 4.199 & 72.4 & 36.71 & 4.487 & 78.7 & 27.76 & 3.326 & 70.1 & 31.56 & 3.823 & 73.2 \\
\hline 29.12 & 3.911 & 72.8 & 32.97 & 4.203 & 70.9 & 36.76 & 4.491 & 79.7 & 27.81 & 3.333 & 64.4 & 31.62 & 3.831 & 74.8 \\
\hline 29.17 & 3.915 & 76.3 & 33.02 & 4.207 & 71.8 & 36.81 & 4.495 & 78.2 & 27.86 & 3.340 & 65.9 & 31.66 & 3.836 & 75.4 \\
\hline 29.21 & 3.918 & 72.2 & 33.06 & 4.210 & 76.0 & 36.86 & 4.499 & 82.0 & 27.91 & 3.346 & 68.7 & 31.71 & 3.842 & 76.4 \\
\hline 29.26 & 3.921 & 68.4 & 33.12 & 4.215 & 76.0 & 36.91 & 4.502 & 75.9 & 27.96 & 3.353 & 70.6 & 31.76 & 3.849 & 73.1 \\
\hline 29.31 & 3.925 & 68.5 & 33.17 & 4.218 & 74.9 & 36.96 & 4.506 & 77.8 & 28.01 & 3.360 & 58.9 & 31.81 & 3.855 & 75.8 \\
\hline 29.36 & 3.929 & 64.6 & 33.21 & 4.221 & 67.5 & 37.02 & 4.511 & 58.4 & 28.06 & 3.367 & 63.2 & 31.86 & 3.862 & 76.4 \\
\hline 29.41 & 3.933 & 68.7 & 33.26 & 4.225 & 77.1 & 37.06 & 4.514 & 70.4 & 28.11 & 3.374 & 63.1 & 31.91 & 3.868 & 79.1 \\
\hline 29.46 & 3.937 & 55.9 & 33.31 & 4.229 & 76.3 & 37.11 & 4.518 & 68.1 & 28.16 & 3.381 & 65.4 & 31.96 & 3.875 & 77.4 \\
\hline 29.52 & 3.941 & 63.0 & 33.36 & 4.233 & 80.8 & 37.16 & 4.521 & 66.5 & 28.21 & 3.388 & 62.3 & 32.01 & 3.881 & 76.1 \\
\hline 29.56 & 3.944 & 69.8 & 33.41 & 4.237 & 77.7 & 37.21 & 4.525 & 75.3 & 28.26 & 3.395 & 70.8 & 32.06 & 3.885 & 80.6 \\
\hline 29.61 & 3.948 & 64.8 & 33.46 & 4.240 & 75.4 & 37.26 & 4.529 & 62.0 & 28.31 & 3.401 & 70.8 & 32.10 & 3.888 & 79.1 \\
\hline 29.66 & 3.952 & 64.1 & 33.51 & 4.244 & 60.7 & 37.31 & 4.533 & 75.4 & 28.36 & 3.408 & 74.1 & 32.16 & 3.893 & 78.9 \\
\hline 29.71 & 3.956 & 70.0 & 33.56 & 4.248 & 71.1 & 37.36 & 4.537 & 72.2 & 28.41 & 3.414 & 70.8 & 32.21 & 3.897 & 76.7 \\
\hline 29.76 & 3.959 & 69.3 & 33.62 & 4.253 & 73.7 & 37.41 & 4.540 & 79.1 & 28.46 & 3.421 & 74.9 & 32.26 & 3.901 & 76.4 \\
\hline 29.81 & 3.963 & 69.5 & 33.67 & 4.256 & 66.5 & 37.47 & 4.545 & 79.4 & 28.51 & 3.427 & 71.4 & 32.31 & 3.905 & 76.5 \\
\hline 29.87 & 3.968 & 72.5 & 33.71 & 4.259 & 69.1 & 37.52 & 4.549 & 77.4 & 28.56 & 3.434 & 73.0 & 32.36 & 3.909 & 73.8 \\
\hline 29.91 & 3.971 & 60.6 & 33.76 & 4.263 & 69.2 & 37.56 & 4.552 & 73.1 & 28.62 & 3.442 & 70.9 & 32.41 & 3.914 & 73.9 \\
\hline 29.97 & 3.975 & 68.8 & 33.81 & 4.267 & 69.2 & 37.62 & 4.556 & 69.4 & 28.66 & 3.447 & 68.2 & 32.46 & 3.918 & 70.2 \\
\hline 30.02 & 3.979 & 65.3 & 33.86 & 4.271 & 66.5 & 37.67 & 4.560 & 73.0 & 28.71 & 3.453 & 71.3 & 32.50 & 3.921 & 67.9 \\
\hline 30.06 & 3.982 & 77.5 & 33.91 & 4.275 & 76.4 & 37.71 & 4.563 & 73.2 & 28.76 & 3.460 & 69.9 & 32.56 & 3.926 & 67.8 \\
\hline 30.12 & 3.987 & 69.4 & 33.96 & 4.278 & 61.3 & 37.76 & 4.567 & 66.4 & 28.81 & 3.466 & 61.8 & 32.61 & 3.930 & 69.1 \\
\hline 30.17 & 3.991 & 69.5 & 34.02 & 4.283 & 68.0 & 37.81 & 4.571 & 83.1 & 28.86 & 3.473 & 58.0 & 32.66 & 3.934 & 70.9 \\
\hline 30.21 & 3.994 & 70.4 & 34.06 & 4.286 & 70.3 & 37.86 & 4.575 & 82.0 & 28.91 & 3.479 & 67.2 & 32.71 & 3.938 & 70.7 \\
\hline 30.26 & 3.997 & 67.3 & 34.11 & 4.290 & 62.3 & 37.91 & 4.578 & 78.2 & 28.96 & 3.486 & 77.9 & 32.76 & 3.942 & 71.2 \\
\hline 30.31 & 4.001 & 74.1 & 34.16 & 4.294 & 73.3 & 37.96 & 4.582 & 81.7 & 29.01 & 3.492 & 73.6 & 32.81 & 3.946 & 70.9 \\
\hline 30.36 & 4.005 & 74.1 & 34.21 & 4.297 & 68.5 & 38.01 & 4.586 & 72.2 & 29.06 & 3.499 & 72.8 & 32.86 & 3.950 & 72.1 \\
\hline 30.41 & 4.009 & 77.7 & 34.26 & 4.301 & 70.2 & 38.06 & 4.590 & 77.6 & 29.10 & 3.504 & 64.6 & 32.91 & 3.954 & 72.1 \\
\hline 30.46 & 4.013 & 71.6 & 34.31 & 4.305 & 73.0 & 38.12 & 4.594 & 80.7 & 29.16 & 3.512 & 59.5 & 32.96 & 3.959 & 69.3 \\
\hline 30.51 & 4.016 & 71.3 & 34.37 & 4.309 & 74.6 & 38.17 & 4.598 & 80.1 & 29.21 & 3.518 & 58.0 & 33.01 & 3.963 & 68.2 \\
\hline 30.56 & 4.020 & 69.5 & 34.41 & 4.313 & 75.6 & 38.21 & 4.601 & 76.7 & 29.26 & 3.525 & 68.5 & 33.06 & 3.967 & 69.8 \\
\hline 30.62 & 4.025 & 70.2 & 34.47 & 4.317 & 67.9 & 38.26 & 4.605 & 74.9 & 29.31 & 3.531 & 63.6 & & & \\
\hline 30.67 & 4.028 & 69.7 & 34.52 & 4.321 & 63.1 & 38.31 & 4.609 & 71.7 & 29.36 & 3.538 & 63.9 & 115-710B-5 & & \\
\hline 30.71 & 4.032 & 76.1 & 34.56 & 4.324 & 81.4 & 38.36 & 4.613 & 83.0 & 29.41 & 3.544 & 67.6 & & & \\
\hline 30.77 & 4.036 & 79.0 & 34.62 & 4.328 & 79.4 & & & & 29.46 & 3.550 & 68.4 & 38.11 & 4.557 & 82.1 \\
\hline 30.81 & 4.039 & 78.9 & 34.67 & 4.332 & 80.8 & $115-710 \mathrm{~B}-4 \mathrm{H}$ & & & 29.50 & 3.556 & 68.2 & 38.16 & 4.561 & 82.2 \\
\hline 30.86 & 4.043 & 70.3 & 34.71 & 4.335 & 72.7 & & & & 29.56 & 3.563 & 69.5 & 38.21 & 4.565 & 81.1 \\
\hline 30.91 & 4.047 & 71.6 & 34.75 & 4.338 & 65.4 & 25.81 & 2.938 & 73.4 & 29.61 & 3.570 & 71.1 & 38.26 & 4.569 & 83.0 \\
\hline 30.96 & 4.051 & 67.9 & 34.81 & $\begin{array}{l}4.350 \\
4.343\end{array}$ & $\begin{array}{l}0.4 \\
67.2\end{array}$ & 25.86 & 2.952 & 63.3 & 29.66 & 3.576 & 72.9 & 38.31 & 4.573 & 83.4 \\
\hline 31.02 & 4.055 & 86.2 & $\begin{array}{l}34.01 \\
34.86\end{array}$ & 4.347 & $\begin{array}{l}0 . .2 \\
75.7\end{array}$ & 25.91 & 2.966 & 66.9 & 29.71 & 3.583 & 73.1 & 38.36 & 4.578 & 81.9 \\
\hline 31.06 & 4.058 & 65.8 & 34.91 & 4.351 & 78.4 & 25.96 & 2.979 & 66.0 & 29.76 & 3.589 & 69.4 & 38.41 & 4.582 & 83.6 \\
\hline 31.11 & 4.062 & 71.2 & 34.96 & 4.354 & 77.1 & 26.01 & 2.993 & 64.2 & 29.81 & $\begin{array}{l}3.509 \\
3.596\end{array}$ & $\begin{array}{l}09.4 \\
64.1\end{array}$ & 38.46 & 4.586 & 77.6 \\
\hline 31.16 & 4.066 & 77.8 & 35.01 & 4.358 & 75.5 & 26.06 & 3.006 & 60.9 & $\begin{array}{l}29.81 \\
29.86\end{array}$ & $\begin{array}{l}3.590 \\
3.602\end{array}$ & 64.6 & $\begin{array}{l}38.40 \\
38.51\end{array}$ & $\begin{array}{l}4.500 \\
4.590\end{array}$ & 79.9 \\
\hline 31.21 & 4.069 & 67.9 & 35.06 & 4.362 & 76.5 & 26.10 & 3.017 & 60.4 & 29.91 & $\begin{array}{l}3.002 \\
3.609\end{array}$ & $\begin{array}{l}0.0 \\
62.4\end{array}$ & 38.56 & 4.594 & 84.7 \\
\hline 31.26 & 4.073 & 69.6 & 35.12 & 4.366 & 75.1 & 26.16 & 3.033 & 58.8 & 29.96 & 3.615 & $\begin{array}{l}02.4 \\
57.1\end{array}$ & 38.61 & 4.598 & 85.3 \\
\hline 31.31 & 4.077 & 72.7 & 35.17 & 4.370 & 70.0 & 26.21 & 3.047 & 61.6 & 30.01 & 3.622 & 68.0 & 38.66 & 4.602 & 85.9 \\
\hline 31.37 & 4.082 & 71.0 & 35.21 & 4.373 & 66.0 & 26.26 & 3.061 & 59.3 & 30.06 & 3.628 & $\begin{array}{l}68.0 \\
62.7\end{array}$ & 38.71 & 4.606 & 82.7 \\
\hline
\end{tabular}


Appendix (continued).

\begin{tabular}{|c|c|c|c|c|c|c|c|c|c|c|c|c|c|c|}
\hline $\begin{array}{l}\text { Depth } \\
\text { (msbf) }\end{array}$ & $\begin{array}{l}\text { Age } \\
(\mathrm{Ma})\end{array}$ & $\begin{array}{c}\mathrm{CaCO}_{3} \\
(\%)\end{array}$ & $\begin{array}{l}\text { Depth } \\
\text { (msbf) }\end{array}$ & $\begin{array}{l}\text { Age } \\
\text { (Ma) }\end{array}$ & $\begin{array}{c}\mathrm{CaCO}_{3} \\
(\%)\end{array}$ & $\begin{array}{l}\text { Depth } \\
\text { (msbf) }\end{array}$ & $\begin{array}{l}\text { Age } \\
(\mathrm{Ma})\end{array}$ & $\begin{array}{c}\mathrm{CaCO}_{3} \\
(\%)\end{array}$ & $\begin{array}{l}\text { Depth } \\
\text { (msbf) }\end{array}$ & $\begin{array}{l}\text { Age } \\
(\mathrm{Ma})\end{array}$ & $\begin{array}{c}\mathrm{CaCO}_{3} \\
(\%)\end{array}$ & $\begin{array}{l}\text { Depth } \\
\text { (msbf) }\end{array}$ & $\begin{array}{l}\text { Age } \\
(\mathrm{Ma})\end{array}$ & $\begin{array}{c}\mathrm{CaCO}_{3} \\
(\%)\end{array}$ \\
\hline $115-710 \mathrm{~B}-5 \mathrm{H}$ & - (Cont.) & & $115-711 \mathrm{~A}-2 \mathrm{H}$ & - (Cont.) & & $115-711 \mathrm{~A}-3 \mathrm{H}$ & 1- (Cont. & & $115-711 \mathrm{~B}-31$ & I- (Cont. & & $115-711 \mathrm{~B}-3 \mathrm{H}$ & - (Cont.) & \\
\hline 38.76 & 4.610 & 83.3 & 9.96 & 1.707 & 38.3 & 19.20 & 4.444 & 12.8 & 13.85 & 3.142 & 2.0 & 17.65 & 4.270 & 0.4 \\
\hline 38.81 & 4.615 & 83.2 & 10.00 & 1.719 & 48.9 & 19.25 & 4.459 & 15.3 & 13.90 & 3.159 & 2.9 & 17.70 & 4.285 & 0.8 \\
\hline 38.86 & 4.619 & 84.8 & 10.05 & 1.734 & 55.1 & 19.30 & 4.474 & 15.3 & 13.95 & 3.176 & 2.9 & 17.75 & 4.299 & 2.5 \\
\hline 38.91 & 4.623 & 81.1 & 10.10 & 1.749 & 36.4 & 19.35 & 4.489 & 18.1 & 14.01 & 3.197 & 5.1 & 17.80 & 4.313 & 2.7 \\
\hline 38.96 & 4.627 & 75.7 & 10.16 & 1.767 & 34.3 & 19.40 & 4.503 & 14.9 & 14.05 & 3.211 & 4.4 & 17.85 & 4.327 & 1.9 \\
\hline 39.01 & 4.631 & 79.3 & 10.20 & 1.778 & 34.6 & 19.45 & 4.518 & 13.7 & 14.10 & 3.228 & 2.1 & 17.90 & 4.342 & 1.7 \\
\hline 39.06 & 4.635 & 83.0 & 10.26 & 1.796 & 45.0 & 19.50 & 4.533 & 13.9 & 14.15 & 3.245 & 3.9 & 17.95 & 4.356 & 1.4 \\
\hline 39.11 & 4.639 & 80.3 & 10.30 & 1.808 & 24.7 & 19.55 & 4.548 & 16.2 & 14.20 & 3.262 & 1.2 & 18.00 & 4.370 & 2.4 \\
\hline 39.16 & 4.643 & 77.9 & 10.36 & 1.826 & 32.5 & 19.60 & 4.563 & 23.7 & 14.25 & 3.279 & 0.7 & 18.05 & 4.385 & 2.1 \\
\hline 39.21 & 4.647 & 79.2 & 10.45 & 1.853 & 29.5 & 19.65 & 4.577 & 21.0 & 14.30 & 3.297 & 1.2 & 18.10 & 4.399 & 1.9 \\
\hline 39.26 & 4.652 & 79.9 & 10.50 & 1.867 & 22.9 & 19.70 & 4.592 & 12.0 & 14.34 & 3.310 & 2.8 & 18.15 & 4.413 & 4.3 \\
\hline 39.31 & 4.656 & 76.3 & 10.55 & 1.882 & 30.4 & 19.75 & 4.607 & 12.6 & 14.40 & 3.331 & 2.7 & 18.20 & 4.427 & 6.3 \\
\hline 39.36 & 4.660 & 76.3 & 10.63 & 1.906 & 43.5 & 19.80 & 4.622 & 25.0 & 14.45 & 3.348 & 3.1 & 18.25 & 4.442 & 2.4 \\
\hline 39.41 & 4.664 & 76.1 & 10.72 & 1.932 & 32.5 & 19.85 & 4.637 & 15.9 & 14.50 & 3.366 & 3.2 & 18.30 & 4.456 & 3.1 \\
\hline 39.46 & 4.668 & 77.3 & 10.77 & 1.947 & 46.7 & 19.90 & 4.652 & 14.6 & 14.55 & 3.383 & 3.0 & 18.35 & 4.470 & 6.0 \\
\hline 39.51 & 4.672 & 79.9 & 10.81 & 1.959 & 44.2 & 19.95 & 4.666 & 16.1 & 14.60 & 3.400 & 2.2 & 18.40 & 4.484 & 6.2 \\
\hline 39.56 & 4.676 & 79.8 & 10.86 & 1.974 & 54.5 & 20.00 & 4.681 & 13.4 & 14.65 & 3.414 & 4.1 & 18.45 & 4.499 & 7.9 \\
\hline 39.61 & 4.680 & 79.3 & 10.91 & 1.989 & 44.4 & 20.05 & 4.696 & 12.6 & 14.70 & 3.429 & 3.7 & 18.50 & 4.513 & 9.1 \\
\hline 39.66 & 4.684 & 76.3 & 10.95 & 2.001 & 35.1 & 20.10 & 4.711 & 9.6 & 14.75 & 3.443 & 1.1 & 18.55 & 4.527 & 16.6 \\
\hline 39.71 & 4.689 & 80.7 & 11.01 & 2.018 & 31.2 & 20.15 & 4.726 & 9.6 & 14.80 & 3.457 & 0.8 & 18.60 & 4.541 & 18.6 \\
\hline 39.76 & 4.693 & 82.5 & 11.06 & 2.033 & 40.6 & 20.22 & 4.746 & 8.2 & 14.85 & 3.471 & 0.8 & 18.65 & 4.556 & 22.5 \\
\hline 39.81 & 4.697 & 84.4 & 11.15 & 2.060 & 33.8 & 20.25 & 4.755 & 7.8 & 14.90 & 3.486 & 0.7 & 18.70 & 4.570 & 23.9 \\
\hline 39.86 & 4.701 & 82.3 & 11.20 & 2.075 & 43.2 & 20.30 & 4.770 & 9.0 & 14.95 & 3.500 & 0.8 & 18.75 & 4.584 & 12.8 \\
\hline 39.89 & 4.703 & 77.4 & 11.25 & 2.089 & 38.9 & 20.34 & 4.782 & 7.5 & 15.00 & 3.514 & 0.9 & 18.80 & 4.599 & 14.8 \\
\hline 39.91 & 4.705 & 75.4 & 11.30 & 2.104 & 33.8 & 20.40 & 4.800 & 8.3 & 15.05 & 3.528 & 0.6 & 18.85 & 4.613 & 15.3 \\
\hline 39.96 & 4.709 & 76.2 & 11.35 & 2.119 & 39.4 & 20.45 & 4.814 & 7.1 & 15.10 & 3.543 & 0.6 & 18.90 & 4.627 & 15.8 \\
\hline 40.01 & 4.713 & 76.2 & 11.39 & 2.131 & 28.5 & 20.50 & 4.829 & 10.2 & 15.15 & 3.557 & 0.7 & 18.95 & 4.641 & 17.6 \\
\hline 40.06 & 4.717 & 73.1 & 11.46 & 2.152 & 40.3 & 20.55 & 4.844 & 7.0 & 15.20 & 3.571 & 0.5 & 19.00 & 4.656 & 14.1 \\
\hline 40.11 & 4.721 & 71.9 & 11.50 & 2.164 & 30.3 & 20.60 & 4.859 & 5.5 & 15.25 & 3.585 & 0.6 & 19.05 & 4.670 & 14.0 \\
\hline 40.16 & 4.726 & 76.8 & 11.55 & 2.178 & 40.5 & 20.65 & 4.874 & 6.9 & 15.30 & 3.600 & 0.4 & 19.10 & 4.684 & 7.4 \\
\hline 40.21 & 4.730 & 79.8 & 11.61 & 2.196 & 38.0 & 20.70 & 4.888 & 6.7 & 15.35 & 3.614 & 0.5 & 19.15 & 4.698 & 7.7 \\
\hline 40.26 & 4.734 & 79.3 & 11.65 & 2.208 & 32.1 & & & & 15.40 & 3.628 & 0.4 & 19.20 & 4.713 & 6.9 \\
\hline 40.31 & 4.738 & 76.8 & 11.70 & 2.223 & 41.8 & $115-711 \mathrm{~B}-3 \mathrm{H}$ & & & 15.45 & 3.643 & 0.4 & & & \\
\hline 40.36 & 4.742 & 77.2 & 11.75 & 2.238 & 26.9 & & & & 15.50 & 3.657 & 0.4 & & & \\
\hline 40.41 & 4.746 & 78.7 & 11.80 & 2.252 & 34.4 & 11.75 & 2.427 & 26.4 & 15.55 & 3.671 & 0.4 & & & \\
\hline 40.47 & 4.751 & 79.3 & 11.85 & 2.267 & 50.3 & 11.80 & 2.441 & 17.5 & 15.60 & 3.685 & 0.6 & & & \\
\hline 40.51 & 4.754 & 78.9 & 11.89 & 2.279 & 28.5 & 11.85 & 2.456 & 19.6 & 15.65 & 3.700 & 0.5 & & & \\
\hline 40.58 & 4.760 & 72.9 & 11.91 & 2.285 & 24.0 & 11.90 & 2.470 & 13.7 & 15.70 & 3.714 & 0.5 & & & \\
\hline 40.61 & 4.763 & 75.9 & 11.95 & 2.297 & 53.5 & 11.95 & 2.487 & 22.1 & 15.75 & 3.728 & 0.5 & & & \\
\hline 40.66 & 4.767 & 75.5 & 12.05 & 2.326 & 41.5 & 12.00 & 2.504 & 21.5 & 15.80 & 3.742 & 0.4 & & & \\
\hline 40.71 & 4.771 & 78.6 & 12.21 & 2.374 & 15.8 & 12.05 & 2.522 & 10.8 & 15.85 & 3.757 & 0.3 & & & \\
\hline 40.76 & 4.775 & 78.2 & 12.27 & 2.392 & 9.8 & 12.10 & 2.539 & 15.6 & 15.90 & 3.771 & 0.3 & & & \\
\hline & & & 12.36 & 2.418 & 13.4 & 12.15 & 2.556 & 27.8 & 15.95 & 3.785 & 0.4 & & & \\
\hline $115-711 \mathrm{~A}-2 \mathrm{H}$ & & & 12.41 & 2.433 & 19.5 & 12.20 & 2.573 & 31.3 & 16.00 & 3.800 & 0.5 & & & \\
\hline & & & 12.45 & 2.445 & 22.7 & 12.25 & 2.591 & 30.4 & 16.05 & 3.814 & 0.6 & & & \\
\hline 8.20 & 1.380 & $\begin{array}{l}14.8 \\
30.8\end{array}$ & 12.51 & 2.463 & 22.4 & 12.30 & 2.608 & 28.4 & 16.10 & 3.828 & 0.6 & & & \\
\hline 8.25 & 1.389 & 30.8 & 12.66 & 2.507 & 28.4 & 12.35 & 2.625 & 19.4 & 16.15 & 3.842 & 0.8 & & & \\
\hline 8.30 & 1.398 & 32.7 & 12.71 & 2.522 & 26.7 & 12.40 & 2.642 & 15.8 & 16.20 & 3.857 & 0.5 & & & \\
\hline 8.35 & 1.406 & 34.0 & 12.76 & 2.537 & 27.3 & 12.45 & 2.659 & 22.0 & 16.25 & 3.871 & 0.6 & & & \\
\hline 8.40 & 1.415 & 24.8 & 12.81 & 2.552 & 28.5 & 12.50 & 2.677 & 15.9 & 16.30 & 3.885 & 0.8 & & & \\
\hline 8.46 & 1.426 & 28.1 & 12.86 & 2.566 & 28.2 & 12.55 & 2.694 & 15.2 & 16.35 & 3.899 & 0.5 & & & \\
\hline 8.51 & 1.434 & 39.4 & 12.90 & 2.578 & 28.1 & 12.60 & 2.711 & 12.8 & 16.40 & 3.914 & 0.5 & & & \\
\hline 8.56 & 1.443 & 47.0 & 12.98 & 2.602 & 18.0 & 12.65 & 2.728 & 11.2 & 16.45 & 3.928 & 0.9 & & & \\
\hline 8.61 & 1.452 & 35.3 & & & & 12.70 & 2.746 & 17.8 & 16.50 & 3.942 & 1.0 & & & \\
\hline 8.65 & 1.459 & 29.9 & $115-711 \mathrm{~A}-3 \mathrm{H}$ & & & 12.75 & 2.763 & 29.2 & 16.55 & 3.956 & 0.5 & & & \\
\hline 8.69 & 1.466 & 37.2 & & & & 12.80 & 2.780 & 30.1 & 16.60 & 3.971 & 1.0 & & & \\
\hline 8.75 & 1.476 & 47.5 & 18.10 & 4.118 & 12.6 & 12.85 & 2.797 & 11.8 & 16.65 & 3.985 & 0.8 & & & \\
\hline 8.80 & 1.485 & 59.2 & 18.15 & 4.133 & 11.7 & 12.90 & 2.814 & 11.1 & 16.70 & 3.999 & 1.2 & & & \\
\hline 8.85 & 1.494 & 82.6 & 18.21 & 4.151 & 7.4 & 12.95 & 2.832 & 9.0 & 16.75 & 4.014 & 0.8 & & & \\
\hline 8.90 & 1.502 & 73.5 & 18.25 & 4.163 & 9.3 & 13.00 & 2.849 & 8.8 & 16.80 & 4.028 & 1.8 & & & \\
\hline 8.95 & 1.511 & 62.8 & 18.30 & 4.178 & 7.4 & 13.05 & 2.866 & 9.0 & 16.85 & 4.042 & 1.9 & & & \\
\hline 9.00 & 1.520 & 56.1 & 18.40 & 4.207 & 1.6 & 13.10 & 2.883 & 7.5 & 16.90 & 4.056 & 0.5 & & & \\
\hline 9.05 & 1.529 & 67.1 & 18.44 & 4.219 & 5.0 & 13.15 & 2.901 & 7.1 & 16.95 & 4.071 & 0.5 & & & \\
\hline 9.10 & 1.538 & 63.3 & 18.50 & 4.237 & 3.1 & 13.20 & 2.918 & 5.7 & 17.00 & 4.085 & 1.1 & & & \\
\hline 9.15 & 1.546 & 58.1 & 18.55 & 4.252 & 8.8 & 13.25 & 2.935 & 8.5 & 17.05 & 4.099 & 1.0 & & & \\
\hline 9.21 & 1.557 & 34.7 & 18.59 & 4.264 & 4.0 & 13.30 & 2.952 & 8.0 & 17.10 & 4.113 & 1.1 & & & \\
\hline 9.30 & 1.572 & 44.4 & 18.66 & 4.284 & 6.7 & 13.35 & 2.969 & 6.3 & 17.15 & 4.128 & 0.8 & & & \\
\hline 9.35 & 1.581 & 77.3 & 18.70 & 4.296 & 5.4 & 13.40 & 2.987 & 3.6 & 17.20 & 4.142 & 0.6 & & & \\
\hline 9.40 & 1.590 & 73.2 & 18.80 & 4.326 & 5.5 & 13.45 & 3.004 & 5.3 & 17.25 & 4.156 & 0.4 & & & \\
\hline 9.50 & 1.607 & 43.8 & 18.84 & 4.338 & 3.4 & 13.50 & 3.021 & 4.3 & 17.30 & 4.170 & 0.4 & & & \\
\hline 9.65 & 1.634 & 21.4 & 18.90 & 4.355 & 4.3 & 13.55 & 3.038 & 2.1 & 17.35 & 4.185 & 0.7 & & & \\
\hline 9.70 & 1.642 & 34.8 & 18.95 & 4.370 & 3.8 & 13.60 & 3.056 & 1.7 & 17.40 & 4.199 & 1.2 & & & \\
\hline 9.75 & 1.651 & 39.8 & 19.00 & 4.385 & 3.0 & 13.65 & 3.073 & 4.9 & 17.45 & 4.213 & 1.2 & & & \\
\hline 9.80 & 1.660 & 35.4 & 19.05 & 4.400 & 4.9 & 13.71 & 3.093 & 2.9 & 17.50 & 4.228 & 1.2 & & & \\
\hline 9.84 & 1.672 & 31.0 & 19.10 & 4.415 & 7.5 & 13.75 & 3.107 & 2.0 & 17.55 & 4.242 & 1.2 & & & \\
\hline 9.90 & 1.690 & 35.4 & 19.15 & 4.429 & 10.8 & 13.80 & 3.124 & 1.8 & 17.60 & 4.256 & 1.5 & & & \\
\hline
\end{tabular}

